\title{
Re-Os systematics and geochemistry of cobaltite (CoAsS) in the Idaho cobalt belt, Belt-Purcell Basin, USA: Evidence for middle Mesoproterozoic sediment- hosted Co-Cu sulfide mineralization with Grenvillian and Cretaceous remobilization
}

\author{
N. J. Saintilan ${ }^{1, *}$, R. A. Creaser ${ }^{1}$, A. A. Bookstrom ${ }^{2}$ \\ ${ }^{1}$ Department of Earth and Atmospheric Sciences, University of Alberta, Edmonton, Alberta, T6G \\ 2E3, Canada \\ ${ }^{2}$ U.S. Geological Survey, 904 W. Riverside Avenue, Spokane, Washington 99201, USA
}

Corresponding author:

Nicolas J. Saintilan

saintilanic@gmail.com

* Present address: Department of Earth Sciences, University of Durham, Durham DH1 3LE, United Kingdom 


\section{Abstract}

We report the first study of the Re-Os systematics of cobaltite (CoAsS) using disseminated grains and massive sulfides from samples of two breccia-type and two stratabound deposits in the $\mathrm{Co}-\mathrm{Cu}-\mathrm{Au}$ Idaho cobalt belt (ICB), Lehmi Sub-basin to the Belt-Purcell Basin, Idaho, USA. Using a ${ }^{185} \mathrm{Re}+{ }^{190} \mathrm{Os}$ spike solution, magnetic and non-magnetic fractions of cobaltite mineral separates give reproducible ReOs analytical data for aliquot sizes of 150 to $200 \mathrm{mg}$. Cobaltite from the ICB has highly radiogenic ${ }^{187} \mathrm{Os} /{ }^{188}$ Os ratios (17-45) and high ${ }^{187} \mathrm{Re} /{ }^{188}$ Os ratios $(600-1800)$ but low Re and total Os contents (ca. $0.4-4 \mathrm{ppb}$ and $14-64 \mathrm{ppt}$, respectively). Containing 30 to $74 \%$ radiogenic ${ }^{187} \mathrm{Os}$, cobaltite from the ICB is amenable to Re-Os age determination using the isochron regression approach.

Re-Os data for disseminated cobaltite mineralization in a quartz-tourmaline breccia from the Haynes-Stellite deposit yield a Model 1 isochron age of $1349 \pm 76 \mathrm{Ma}(2 \sigma, n=4$, mean squared weighted deviation MSWD $=2.1$, initial ${ }^{187} \mathrm{Os} /{ }^{188} \mathrm{Os}$ ratio $=4.7 \pm 2.2$ ). This middle Mesoproterozoic age is preserved despite a possible metamorphic overprint or a pulse of metamorphic-hydrothermal remobilization of pre-existing cobaltite that formed along fold cleavages during the ca. 1190-1006 Ma Grenvillian orogeny. This phase of remobilization is tentatively identified by a Model 3 isochron age of $1132 \pm 240 \mathrm{Ma}\left(2 \sigma, n=7, \mathrm{MSWD}=9.3\right.$, initial ${ }^{187} \mathrm{Os} /{ }^{188} \mathrm{Os}$ ratio of $\left.9.0 \pm 2.9\right)$ for cobaltite in the quartztourmaline breccia from the Idaho zone.

All Mesoproterozoic cobaltite mineralization in the district was affected by greenschist- to lower amphibolites-facies (garnet zone) metamorphism during the Late Jurassic to Late Cretaceous Cordilleran orogeny. However, the fine- to coarse-grained massive cobaltite mineralization from the shear zonehosted Chicago zone is the only studied deposit that has severely disturbed Re-Os systematics with evidence for a linear trend of mixing with (metamorphic?) fluids.

The new Re-Os ages and extremely high initial ${ }^{187} \mathrm{Os} /{ }^{188} \mathrm{Os}$ ratios of cobaltite reported here favor a magmatic-hydrothermal genetic model for a multi-stage REE-Y-Co-Cu-Au mineralization occurring at ca. 1370 to $1349 \mathrm{Ma}$, and related to the emplacement of the Big Deer Creek granite pluton at ca. $1377 \mathrm{Ma}$. In our model, deposition of paragenetically early xenotime and gadolinite was followed by an influx of 
Mesoproterozoic evaporitic brines and magmatic-hydrothermal fluids containing metals and reduced sulfur derived from mafic and oceanic island-arc Archean to Paleoproterozoic rocks in the Laurentian basement. Cobaltite mineralization (and the closure of the Re-Os isotopic system in this mineral) occurred upon cooling of these fluids at an inferred temperature of $300^{\circ} \mathrm{C}$ or below.

Keywords cobaltite, Re-Os, geochronology, Mesoproterozoic, metamorphism, greenschist, Idaho cobalt belt, magmatic-hydrothermal, xenotime, Great Falls tectonic zone 


\section{Introduction}

Cobaltite-CoAsS-, which crystallizes in the orthorhombic system, belongs to the group of sulfarsenide minerals that includes gersdorffite (NiAsS, cubic) and arsenopyrite (FeAsS, monoclinic). Cobaltite is found in a variety of ore deposits, including mafic to ultramafic-hosted massive sulfide deposits (e.g., Main Uralian fault zone, southern Urals: Nimis et al., 2008), orogenic gold deposits (e.g., Oberon gold prospect, Northern Territory, Australia: Cook et al., 2013; Huston et al., 2007; Tunks and Cooke, 2007; Loulo mining district, Mali: Lawrence et al., 2013; Otago and Alpine schists, New Zealand: Pitcairn et al., 2006), some multi-element vein deposits (e.g., Bou Azzer, Morocco: Ahmed et al., 2009). and sediment-hosted Co-Cu deposits of the Idaho cobalt belt, Idaho, USA (cf. Bookstrom et al., 2016). Cobaltite is also known to crystallize with gersdorffite from immiscible sulfarsenide liquid derived from calc-alkaline magma (Beziat et al., 1996).

Other (sulf-)arsenide minerals such as arsenopyrite and löllingite ( $\mathrm{FeAs}_{2}$, orthorhombic) are known hosts for both rhenium (Re) and osmium (Os) with Re concentrations being on the order of 10 to 1000s of ppb, and, Os concentrations in the 10-100s ppt range and up to the ppb level. The Re-Os isotopic system in these minerals has been used for isochron ages that constrain the timing of gold mineralization in hydrothermal gold deposits (Mikulski et al., 2005; Davies et al., 2010; Morelli et al., 2010) and for bringing new insights into the metamorphic evolution of the Broken Hill Pb-Zn-Ag district in Australia (Saintilan et al., 2017). These results and the similarity of crystalline structure between cobaltite and löllingite form a logical basis to investigate the Re-Os isotope system in cobaltite and evaluate the potential of this mineral for Re-Os age determination.

In this study, cobaltite was sampled from $\mathrm{Co}-\mathrm{Cu}-\mathrm{Au}$ deposits hosted by metasedimentary rocks of the Idaho cobalt belt in east-central Idaho, USA (Fig. 1). This metallogenic province was chosen as the best example for which the parameters of basin stratigraphy, structural and tectonic features, and metamorphic history are well constrained by geological and geochronological evidence (Lund and Tysdal, 2007; Zirakparvar et al., 2007; Lund et al., 2011; Aleinikoff et al., 2012; Bookstrom et al., 2016). We chose to focus on (1) the Haynes-Stellite deposit, (2) the Chicago and Idaho zones of the Blackbird mine, 
and (3) the Black Pine prospect to the southeast of the Blackbird area (Fig. 1B). However, no geochronological data exist on the $\mathrm{Co}$ - and $\mathrm{Cu}$-rich sulfide minerals within these deposits; both Proterozoic (Aleinikoff et al., 2012; Slack, 2012; Bookstrom et al., 2016) and Cretaceous (Lund et al., 2011) ages for mineralization have been proposed. This unresolved issue of the timing of mineralization underlies the debate on the best genetic model for $\mathrm{Co}-\mathrm{Cu}$-Au mineralization in the Idaho cobalt belt (Nold, 1990; Slack, 2006; Lund et al., 2011; Slack, 2012).

Herein, we report the results of a two-fold Re-Os investigation of cobaltite mineralization to: (1) assess the degree of preservation of the Re-Os systematics of cobaltite in the four deposits through Cretaceous greenschist- to lower amphibolite-facies metamorphic overprint, and (2) determine if the cobaltite mineralization is Proterozoic or Cretaceous in age for each of the deposits studied. Given the framework in which Re-Os isotope data can be assessed and interpreted further by using available geologic, petrographic, and stable and radiogenic isotope data (Slack, 2006; Slack, 2012; Johnson et al., 2012; Panneerselvam et al., 2012; Bookstrom et al., 2016), our new Re-Os ages for cobaltite mineralization provide a better understanding of the origin of these deposits and the derived initial Os ratios further constrain the source of Os, and by inference, other metals such as Co.

\section{Geology and chronostratigraphy of the Idaho cobalt belt}

The Idaho cobalt belt (ICB; Fig. 1), in the Salmon River Mountains of east-central Idaho, USA, is a northwest-trending belt containing 45 known cobalt $(\mathrm{Co}) \pm$ copper $(\mathrm{Cu}) \pm$ gold $(\mathrm{Au})$-bearing mineral deposits and occurrences (Johnson et al., 1998). Mineralization is hosted by metasedimentary rocks of the Lemhi sub-basin within the southwestern part of the Mesoproterozoic Belt-Purcell basin, which is east of and inboard from the Late Neoproterozoic rifted continental margin (Fig. 1A). Rocks of the western BeltPurcell basin underwent regional metamorphism during the middle to late Mesoproterozoic (Ectasian and Stenian) and during the Jurassic-Tertiary interval, with magmatism occurring during Ectasian, Neoproterozoic, Cambrian-Ordovician, and Triassic-Tertiary time periods (Bookstrom et al., 2016, and references therein). 
$\mathrm{Co}-\mathrm{Cu}-\mathrm{Au}$ occurrences of the ICB are hosted by the coarse siltite and banded siltite units of the Apple Creek Formation and the Gunsight Formation of the Lemhi Group (Fig. 1B; Fig. 2). In the ICB, the coarse siltite unit consists mostly of biotitic siltite whereas the banded siltite unit comprises mostly interlayered siltite and biotite phyllite to schist (after argillite; Bookstrom et al., 2016). Depositional ages of these rocks are bracketed by the youngest sets of detrital zircons in samples from the underlying Hoodoo Formation (ca. 1445 Ma; Link et al., 2007) and from the uppermost part of the banded siltite unit (ca. 1409 Ma; Aleinikoff et al., 2012).

The granite pluton of Big Deer Creek, which bounds the northeastern margin of the ICB, belongs to a bimodal suite of A-type megacrystic granite and meta-gabbroid intrusions that was dated at $1377 \pm 4$ Ma (Aleinikoff et al., 2012). Gabbroic to syenitic plutons (dated at 485-530 Ma; Gillerman, 2008; Lund et al., 2011) and chemically similar mafic dikes represent within-plate magmatism, inboard from the Late Neoproterozoic rifted continental margin, associated with early subsidence and growth of the Cordilleran miogeocline in Cambrian-Ordovician time (Evans, 1984; Lund et al., 2010; Bookstrom et al., 2016).

Structurally, the metasedimentary host rocks to the ICB, the granite pluton of Big Deer Creek, and the syenitic Deep Creek plutons are within the Poison Creek thrust plate which is bounded by the Poison Creek and Iron Lake thrust faults of Cretaceous age (Fig. 1B, Fig. 3). The Blackbird Co-Cu-Au deposit lies within a structural block between the Little Deer and White Ledge faults of Cretaceous age (Fig. 1B). Nold (1990) recognized that ore minerals and metasedimentary host rocks of the ICB are increasingly deformed, metamorphosed, and recrystallized from southeast to northwest (Fig. 1A). Phyllitic biotite- and chlorite-bearing rocks of greenschist facies at the southeast end of the ICB pass northwestward to schistose garnet- and biotite-bearing rocks of lower amphibolite facies in the northwest part of the Blackbird mine area, and to gneissic sillimanite-garnet-biotite-quartz rocks of upper amphibolite facies at the northwest end of the ICB (Bookstrom et al., 2016). Inasmuch as the lower boundary of the garnet zone is gradational, it appears that the thermal gradient increases structurally upward, possibly in the footwall of a hotter thrust plate that overrode the northwestern part of the ICB before being removed during uplift and erosion (Fig. 3). As a result of this tectono-thermal setting, three metamorphic and/or structural 
domains in this order upwards are sandwiched between the Poison Creek and Indian Creek faults, from structurally lowest to highest as follows: (1) the lowermost domain called the "Haynes-Stellite domain" features lower- to middle-greenschist facies rocks; (2) then the middle "Blackbird domain" is characterized by middle- to upper-greenschist facies rocks that contains the Idaho and Chicago mineralized zones within the Blackbird mine; and (3) the uppermost Indian Creek metamorphic domain of upper-greenschist to lower-amphibolite facies rocks, and rocks above the garnet isograd (Fig. 3; cf. Lund et al., 2011).

\section{Mineral deposits, available geochronological constraints, and sampling}

\subsection{Blackbird mine area}

The Blackbird deposit is central to the ICB and contains at least eight strata-bound and semiconcordant ore zones (e.g., Chicago and Idaho zones), several strata-bound prospects (e.g., Merle), and many prospects comprising discordant veins (e.g., Sunshine), mineralized breccias, and small replacement-style occurrences. A minimum estimate of total resources of the Blackbird district was reported by Slack (2013) as $16.8 \mathrm{Mt}$ of ore averaging $0.73 \% \mathrm{Co}, 1.37 \% \mathrm{Cu}$, and $1 \mathrm{ppm} \mathrm{Au}$. This estimate does not include downward projections of ore zones that are open down-dip.

In the Blackbird mine area, strata-bound cobaltite-biotite \pm tourmaline ore zones are preferentially hosted in biotite-rich layers in banded siltite, which is deformed into large- and small-scale, chevron-style folds that plunge moderately northward. The Idaho mineralized zone is hosted by biotite-rich rocks in the tightly crumpled hinge zone of a large-scale chevron-style syncline, where cobaltite-biotite ore shoots are elongate parallel to fold axes. The Chicago zone dips northeastward along the southwest limb of the above-mentioned syncline. Unaltered banded siltite consists of interlayered siltite and argillite, but in cobaltite-biotite ore, argillite is "altered" to biotitite containing $>75 \%$ dark greenish-black biotite that is rich in ferrous iron and chlorine, and is interpreted as hydrothermal in origin (Bookstrom et al., 2016). Two samples used for Re-Os analysis were taken from (1) the tabular and vein-like body of the Chicago 
zone $(\mathrm{CH})$ where alternating bands of massive, coarse-grained, and fine-grained cobaltite are surrounded by greenish-black biotite, and; (2) the quartz-tourmaline-cobaltite breccias within the Idaho zone (ID; Slack, 2012; Bookstrom et al., 2016; Fig. 1B, Fig. 4).

Oscillatory-zoned xenotime grains intergrown with biotite in cobaltite-biotite ore, which formed at $1370 \pm 4$ Ma during a late stage of hydrothermal activity related to intrusion of the Big Deer Creek granite (in situ U-Pb SHRIMP ages, Aleinikoff et al., 2012). Xenotime also occurs as inclusions in cobaltite at the Merle prospect. These authors proposed that the first generation of cobaltite is thus younger than ca. 1370 Ma. Slack (2012) suggested that the 1370 Ma hydrothermal system responsible for xenotime growth also triggered the precipitation of cobaltite (with xenotime inclusions), plus chalcopyrite and gold during a later stage of mineralization. Additional Proterozoic xenotime precipitation occurred at 1315 to $1270 \mathrm{Ma}$ and ca. $1050 \mathrm{Ma}$; however, no introduction of metals is known during these times elsewhere in the Belt-Purcell basin (Aleinikoff et al., 2012).

Mafic dikes of probable Cambrian-Ordovician age cut older cobaltite-biotite lodes in the Blackbird district but are in turn cut by younger quartz-siderite-Fe-Cu-sulfide veins and breccias \pm minor cobaltian arsenopyrite. These Fe-Cu-sulfide-bearing veins and breccias are unfolded and lack metamorphic fabrics (Bookstrom et al., 2016). Lund et al. (2011) determined a ${ }^{40} \mathrm{Ar} /{ }^{39} \mathrm{Ar}$ age of $83 \pm 1 \mathrm{Ma}$ for a muscovite selvage surrounding a late quartz veinlet in previously biotitized host rocks at the Sunshine prospect. This Late Cretaceous age is in accord with late Early Cretaceous (110 $\pm 3 \mathrm{Ma})$ to early Late Cretaceous (92 $\pm 5 \mathrm{Ma}$ ) in situ U-Pb SHRIMP ages of monazite that locally encloses cobaltite in places at the Merle prospect (Alenikoff et al., 2012). This Cretaceous hydrothermal event also triggered the growth of xenotime grains or rims in conjunction with late cobaltite. Garnets in cobaltite-bearing samples from the northwestern part of the ICB (Salmon Canyon deposit) yield Late Jurassic to Late Cretaceous Lu-Hf ages of ca. 151 to $94 \mathrm{Ma}$. Garnet porphyroblasts occurring within these ore zones and others in the Blackbird district typically contain cobaltite inclusions, which is consistent with a preCretaceous age for the cobaltite-biotite ore (Zirakparvar et al., 2007; Bookstrom et al., 2016). 


\subsection{Haynes-Stellite mine}

The Haynes-Stellite mine (HS in Fig. 1B) produced a small tonnage of cobaltite-rich ore from a pipe-like ore body within a northwest-striking and steeply-dipping tabular quartz-tourmaline breccia. This breccia cuts quartzite with thin interbeds of biotite phyllite near the base of the Gunsight Formation (which overlies the banded siltite unit, according to Evans and Green, 2003). The dated sample (Fig. 4) contains aligned lenticular clasts of quartz and quartz-tourmaline breccia in a matrix of tourmaline with cobaltite stringers, brecciated during multiple high-velocity upward fluid flux events (Bookstrom et al., 2016).

\subsection{Black Pine mine and prospects}

The Black Pine mine and neighboring prospects are about $14 \mathrm{~km}$ southeast of the Blackbird mine (Fig. 1B), where host rocks are in thin-bedded banded siltite, consisting of interlayered siltite and locally chloritized biotite phyllite (sample in Fig. 4). The lower level of the Black Pine mine followed thin concordant and discordant veins of a strata-bound copper zone; the upper level followed a strata-bound cobalt zone. These mineralized zones and their host strata generally strike northwest and dip about $60^{\circ}$ northeast. Chalcopyrite, pyrite, and arsenopyrite are the main ore minerals, but quartz, siderite, cobaltian arsenopyrite, cobaltite, and magnetite are also present in some veins and mineralized breccias (Nold, 1990; Bookstrom, 2013).

\section{Material and methods}

\subsection{Sample preparation}

Four samples of cobaltite mineralization from the ICB (Fig. 4) were processed prior to Re-Os isotope geochemistry: (1) a tourmalinized breccia from the Haynes-Stellite deposit (HS, Fig. 4a) composed of quartz, biotite, K-feldspar, and xenotime cemented by disseminated brownish-pink cobaltite; (2) layered ore from the Chicago Zone ( $\mathrm{CH}$, Fig. 4b) of the Blackbird mine, consisting of massive coarsegrained to fine-grained, brownish-pink cobaltite \pm xenotime; (3) layered ore from the Idaho Zone (ID, Fig. 
4c) of the Blackbird mine, comprising disseminated brownish-pink cobaltite within a biotite, quartz, Kfeldspar rock; and, (4) coarse-grained disseminated ore from the Black Pine deposit (BP, Fig. 4d) consisting of shiny gray cobaltite in a quartz-chlorite rock.

All samples were cut into slabs that were thoroughly cleaned using silicon carbide grit and paper to remove any metal traces left by hammering or sawing (Fig. 5). These samples were crushed using an agate mortar and pestle, and sieved through disposable, home-made nylon sieves to produce 70-200 and +70 mesh size fractions. Following heavy liquid separation using Sodium Polytungstate (SPT, specific gravity of 2.86), a Frantz Isodynamic Separator was used to produce magnetic (M) and non-magnetic (NM) cobaltite fractions from the 70-200 mesh fractions, by applying successive $0.3,0.6$, and 0.9 amp currents to all samples (except the Black Pine sample for which 1.8 and 2.1 amp currents were applied), with $15^{\circ}$ side slope and $10^{\circ}$ forward slope configurations. The composition of each mineral separate was verified by $\mathrm{X}$-ray diffraction (XRD) analysis. Aliquots of each magnetic fraction were embedded in epoxy and the mounts were studied by scanning electron microscopy (SEM) using a Zeiss Sigma 300 Field Emission SEM (VP-FESEM) operated in backscattered electron mode (SEM-BSE, beam conditions 15kV). In addition, a Bruker energy-dispersive X-ray spectroscopy (EDS) system with dual silicon-drift detectors, each having an area of $60 \mathrm{~mm}^{2}$ and a resolution of $123 \mathrm{eV}$, was used for single-spot analysis to further control the mineralogy of each mineral separate. After magnetic separation, the final mineral separates contained $~ 50-100 \%$ cobaltite, $0-50 \%$ non-sulfide gangue minerals (e.g., xenotime, quartz, biotite) in all samples, and up to $1 \%$ native gold and up to $0.5 \%$ Bi-telluride in the Chicago Zone sample.

\subsection{Cobaltite petrography and major and trace element chemistry of cobaltite}

Detailed petrography of each cobaltite fraction mounted in epoxy was complemented by major and trace element analysis. Compositional analyses were performed at the Department of Earth \& Atmospheric Sciences, University of Alberta, Edmonton, Canada on a Cameca SX-100 electron microprobe equipped with five wavelength-dispersive spectrometers. Operating conditions were $40^{\circ}$ takeoff angle and beam with energy of $20 \mathrm{keV}$, current set at $20 \mathrm{nA}$, and diameter of $2 \mu \mathrm{m}$. Elements were 
acquired using analyzing crystals LLIF for $\mathrm{As} \mathrm{K} \alpha, \mathrm{Co} \mathrm{K} \alpha, \mathrm{Cu} \mathrm{K} \alpha, \mathrm{Fe} \mathrm{K} \alpha, \mathrm{Zn} \mathrm{K} \alpha$, Ni K $\alpha$, PET for Te L $\beta$, Bi M $\alpha$, Te L $\beta$ (2), Bi M $\alpha$ (2), S K $\alpha$, and LTAP for Se L $\beta$. Standards were Ni metal for Ni K $\alpha$, Cu metal for $\mathrm{Cu} \mathrm{K} \alpha$, Co metal for $\mathrm{Co} \mathrm{K} \alpha$, gallium arsenide (GaAs) for $\mathrm{As} \mathrm{K} \alpha$, bismuth telluride $\left(\mathrm{Bi}_{2} \mathrm{Te}_{3}\right)$ for $\mathrm{Bi} \mathrm{M} \alpha$, Te $\mathrm{L} \beta$, Bi M $\alpha$, Te $\mathrm{L} \beta$, gallium selenide $(\mathrm{GaSe})$ for $\mathrm{Se} \mathrm{L} \beta$, iron disulfide $\left(\mathrm{FeS}_{2}\right)$ for $\mathrm{Fe} \mathrm{K} \alpha$, and sphalerite (ZnS) for $\mathrm{S} \mathrm{K \alpha}, \mathrm{Zn} \mathrm{K \alpha}$. Counting times were 30 seconds for each element, with off-peak counting times of 30 seconds. Off-peak corrections were linear for all elements. Unknown and standard intensities were corrected for deadtime; standard intensities were corrected for standard drift over time. Interference corrections were applied to $\mathrm{S}$ for interference by $\mathrm{Co}$, and Te for interference by $\mathrm{Cu}$ (Donovan et al., 1993). Detection limits (at 99\% confidence level) are 0.02 wt.\% for $\mathrm{Co}, \mathrm{Cu}, \mathrm{S}$, and $\mathrm{Zn}, 0.01$ wt.\% for $\mathrm{Fe}, 0.03$ wt.\% for Ni, 0.05 wt.\% for As, 0.07 wt. \% for Te, 0.09 wt.\% for Bi, and 0.12 wt. \% for Se. The matrix correction method used was ZAF or Phi-Rho-Z calculations, and the mass absorption coefficients dataset was LINEMU. The ZAF or Phi-Rho-Z algorithm utilized was Conventional Philibert/Duncumb-Reed (Armstrong, 1988).

\subsection{Re-Os analytical procedures}

For each analysis, between 50 and $350 \mathrm{mg}$ of cobaltite mineral separate was weighed and transferred into a thick-walled borosilicate Carius tube. Each separate was dissolved in inverse aqua regia $\left(\sim 2 \mathrm{~mL}\right.$ of $10 \mathrm{~N} \mathrm{HCl}$ and $\left.\sim 6 \mathrm{~mL} 16 \mathrm{~N} \mathrm{HNO}_{3}\right)$ together with a known amount of ${ }^{185} \mathrm{Re}+{ }^{190} \mathrm{Os}$ spike solution, at $210^{\circ} \mathrm{C}$ for 24 hours (Fig. 5). The full Re-Os laboratory protocol used in the present work is described in detail by Hnatyshin et al. (2016). Re and Os isotopic compositions were determined by negative thermal ionization mass spectrometry (NTIMS) using a ThermoScientific Triton mass spectrometer at the Canadian Centre for Isotopic Microanalysis, University of Alberta, Edmonton, Canada. Rhenium was measured as $\mathrm{ReO}_{4}^{-}$in static mode on Faraday collectors, whereas Os was measured as $\mathrm{OsO}_{3}{ }^{-}$in peakhopping mode on SEM with a constant flow of oxygen (Creaser et al., 1991; Völkening et al., 1991; Hnatyshin et al., 2016). Measurement quality was monitored by repeated analysis of in-house Re 
$\left({ }^{185} \mathrm{Re} /{ }^{187} \mathrm{Re}=0.59774 \pm 0.00065, n=23\right)$ and Os (“AB-2 standard”, ${ }^{187} \mathrm{Os} /{ }^{188} \mathrm{Os}=0.10682 \pm 0.00009, n=$ 100) standard solutions. Total procedural blanks for each set of samples are reported in Table 1.

All Re-Os ages are reported as Model 1 or Model 3 isochrons obtained through regression in ${ }^{187} \mathrm{Os} /{ }^{188}$ Os vs. ${ }^{187} \mathrm{Re} /{ }^{188} \mathrm{Os}$ space of the Re-Os data (reported at the $2 \sigma$ level $=95 \%$ level of confidence). The Isoplot v. 4.15 program (Ludwig, 2011) was used for isochron regression by considering the ${ }^{187} \operatorname{Re}$ decay constant of $1.666 \mathrm{e}^{-11}$ year $^{-1}$ (Smoliar et al., 1996).

\section{Results}

\subsection{Petrography of the cobaltite mineral fractions}

SEM-BSE images of the different cobaltite mineral fractions studied are shown in Figure 6. Mineral separates (M0.6, M0.9, and NM0.9) from the Chicago zone are characterized by densely packed cobaltite grains up to $15 \mu \mathrm{m}$ in diameter with about 10 to $20 \mathrm{vol} \%$ gangue minerals (mainly biotite) occurring in the M0.6 and M0.9 fractions (Figs. 6a and b). The NM0.9 fraction contains 95 vol\% cobaltite with up to 5 vol\% gold; Bi-tellurides make up to 1-2 vol\% of the M0.6 and M0.9 separates (Figs. 6a, b, and c). The unique M0.9 mineral fraction from the Haynes-Stellite deposit comprises cobaltite $(70-80 \%, 10-50 \mu \mathrm{m}$ in width), biotite, K-feldspar, quartz, and xenotime (Figs. 6d and e). Xenotime overgrows and hence postdates precipitation of cobaltite. Cobaltite crystals have sharp edges where in contact with gangue minerals, but irregular, dented edges where in contact with xenotime. The M0.3 and M0.6 mineral fractions from the Idaho zone contain ca. 5 to 10 vol\% euhedral to subhedral cobaltite (5-35 $\mu \mathrm{m}$ in width) embedded in gangue minerals, mainly quartz, sulfur-bearing Na-silicate (tentatively identified as $\mathrm{SO}_{4^{-}}$ bearing scapolite) and up to 3 to 4 vol\% xenotime (Figs. $6 \mathrm{~g}$ and h).

\subsection{Major and trace element chemistry of cobaltite mineral fractions}

A total of 159 electron microprobe (EMP) analyses were performed on the 70-200 mesh fractions of cobaltite from the Chicago and Idaho zones, the Haynes-Stellite deposit, and the Black Pine prospect (Electronic Supplementary Material 1). In addition to the major elements (Co, As, and S), Fe, and Ni were 
detected in all studied fractions; $\mathrm{Zn}$ was locally detected (limit 0.03 wt.\%) and $\mathrm{Cu}$ was only detected $(<0.55$ wt.\%, Table 2$)$ in fractions from the Haynes-Stellite deposit. Selenium was not detected in any fraction. Tellurium contents are uniformly below $0.10 \mathrm{wt} \%$, whereas Bi reaches $0.2 \mathrm{wt} . \%$ at maximum. Based on the mineralogy of the cobaltite mineral fraction, it is suggested that these accessory elements are contributed by micro-inclusions of Bi-telluride, particularly in samples from the Chicago zone (Fig. 6). The various fractions from each mineral deposit have similar compositions despite variable magnetic susceptibilities (Table 3). Considering the relative positions and metamorphic grade of each studied mineral deposit in the NW-SE striking Idaho Cobalt Belt and the metamorphic grade of each mineral deposit in the ICB (Figs. 1B and 3), cobaltite in the northwesternmost Chicago zone (middle to upper greenschist-facies) has the lowest $\mathrm{Co}$ and highest Ni contents $\left(\mathrm{Fe}_{0.06-0.07} \mathrm{Co}_{0.88-0.89} \mathrm{Ni}_{0.04} \mathrm{As}_{1.03} \mathrm{~S}_{0.97-0.98} ;\right.$ Fig. 7). Cobalt and Ni contents in cobaltite in the Idaho zone, located in the same metamorphic domain as the Chicago zone, has slightly higher $\mathrm{Co}$ and lower $\mathrm{Ni}$ contents $\left(\mathrm{Fe}_{0.05-0.06} \mathrm{Co}_{0.92-0.93} \mathrm{Ni}_{0.02} \mathrm{As}_{1.01} \mathrm{~S}_{0.99}\right)$. Cobaltite in the lowermost Haynes-Stellite structural block, within lower- to middle-greenschist facies strata, has a mineral composition in the range of that found in the Idaho zone $\left(\mathrm{Fe}_{0.05} \mathrm{Co}_{0.92} \mathrm{Ni}_{0.02} \mathrm{As}_{1.02} \mathrm{~S}_{0.98}\right)$. Cobalt mapping via EMP reveals that cobaltite in the Haynes-Stellite mineral fraction displays oscillatory zoning with respect to Co (Fig. 6f). Outside of the Blackbird domain, towards the southeast, cobaltite at the Black Pine prospect is devoid of $\mathrm{Ni}$ and has the highest Co contents encountered in the current work $\left(\mathrm{Fe}_{0.05-0.06} \mathrm{Co}_{0.94-0.95} \mathrm{Ni}_{0.00} \mathrm{As}_{1.02} \mathrm{~S}_{0.98}\right)$.

\subsection{Re-Os results for cobaltite mineral fractions}

Results for four analyses of cobaltite mineral separates from Black Pine did not yield reliable Re-Os isotope data because of low Re concentrations ( $<0.3 \mathrm{ppb}$; Table 3$)$. By contrast, $23 \mathrm{Re}-\mathrm{Os}$ isotope analyses of cobaltite separates from the Chicago zone $(n=7)$, Idaho zone $(n=10)$, and Haynes-Stellite deposit $(n=$ 6) have detectable Re and Os concentrations (Table 3). Osmium concentrations range from 12 to $64 \mathrm{ppt}$ whereas Re concentrations range from 0.4 to $3.4 \mathrm{ppb}$. Uncertainties $( \pm 2 \sigma)$ are $0.89 \%$ or better for $\operatorname{Re}$ abundances, and $9.7 \%$ or better for Os, except seven outliers having uncertainties $>12 \%$. These outliers 
are readily explained by higher percentages of Re and Os blanks ( $2.8 \%$ and $0.75 \%$, respectively). Ratios of ${ }^{187} \mathrm{Re} /{ }^{188} \mathrm{Os}$ vary from 512 to 1818 . Ratios of ${ }^{187} \mathrm{Os} /{ }^{188} \mathrm{Os}$ range from 17.4 to 44.2 . These isotopic ratios are highly radiogenic; thus, these mineral fractions of these deposits qualify as Low-Level Highly Radiogenic (LLHR) samples (Stein et al., 2000). There is no trend of magnetic fractions having more radiogenic ${ }^{187} \mathrm{Os} /{ }^{188} \mathrm{Os}$ ratios relative to the non-magnetic fractions (e.g., NM0.9 vs. M0.6 \& M0.9 for the Chicago zone), to the "less" magnetic fractions (e.g., M0.6 vs. M0.3 for the Idaho zone).

Data points for the Chicago zone samples scatter greatly, not defining any cluster nor linear trend in a ${ }^{187} \mathrm{Re} /{ }^{188} \mathrm{Os}$ vs. ${ }^{187} \mathrm{Os} /{ }^{188}$ Os plot (Fig. 8). By contrast, data points for samples from the Idaho zone and the Haynes-Stellite deposit plot in particular fields of this diagram. Most data points for the Idaho zone plot along, or close to, a $1100 \mathrm{Ma}$ reference isochron (initial ${ }^{187} \mathrm{Os} /{ }^{188} \mathrm{Os}$ ratio of 9), with two outliers closer to the $1200 \mathrm{Ma}$ reference isochron (same initial ${ }^{187} \mathrm{Os} /{ }^{188} \mathrm{Os}$ ratio). In contrast, data points for the Haynes-Stellite deposit plot close to a 1300 Ma reference isochron (initial ${ }^{187} \mathrm{Os} /{ }^{188}$ Os ratio of 5), with two outliers plotting close to a $1500 \mathrm{Ma}$ reference isochron (same initial ${ }^{187} \mathrm{Os} /{ }^{188} \mathrm{Os}$ ratio). The ten data points for the Idaho zone define a Model 3 isochron with an age of $1105 \pm 240 \mathrm{Ma}(2 \sigma$; mean squared weighted deviates, $\mathrm{MSWD}=7.5$, initial ${ }^{187} \mathrm{Os} /{ }^{188}$ Os ratio $[\mathrm{Os}] \mathrm{i}=9.5 \pm 2.9$; Fig. 9). However, three data points display extremely large error ellipses. These uncertainties are explained by high Re blank contributions for these analyses (Table 3). Regression of the seven other data points yields a Model 3 isochron age of 1132 $\pm 240 \mathrm{Ma}\left(2 \sigma ; \mathrm{MSWD}=9.3\right.$, initial ${ }^{187} \mathrm{Os} /{ }^{188} \mathrm{Os}$ ratio $\left.[\mathrm{Os}] \mathrm{i}=9.0 \pm 2.9\right)$.

The four data points for cobaltite from the Haynes-Stellite deposit that plot close to the $1300 \mathrm{Ma}$ reference isochron all have aliquot weights above $200 \mathrm{mg}$. These data points define a Model 1 isochron age of $1349 \pm 76 \mathrm{Ma}\left(2 \sigma ; \mathrm{MSWD}=2.1\right.$, initial ${ }^{187} \mathrm{Os} /{ }^{188} \mathrm{Os}$ ratio $[\mathrm{Os}] \mathrm{i}=4.7 \pm 2.2$; Fig. 10$)$. The two outliers mentioned above have aliquot weights of 50 and $145 \mathrm{mg}$, and present large uncertainties and extended error ellipses due to high Re blank contributions (also a high Os contribution for the aliquot having a weight of $50 \mathrm{mg}$; Table 3). 


\section{Discussion}

\subsection{Cobaltite textures, chemistry, metamorphism, and Re-Os age validation}

Fine-grained cobaltite from the Haynes-Stellite deposit displays oscillatory zoning with respect to Co in which Co contents vary over 5wt. \% (Table 2, Figs. 6 f and 7). Within the lower to middle greenschist-facies Haynes-Stellite structural block (Fig. 3), cobaltite shows limited recrystallization as illustrated by the coexistence of very small grains $(<10 \mu \mathrm{m})$ among a few larger cobaltite crystals (ca. 20 to $50 \mu \mathrm{m}$; Fig. 6). An isochronous behavior is observed for four Re-Os data points (all fine-grained cobaltite separates) that correspond to aliquots having weights above $200 \mathrm{mg}$ (Fig. 8). The other two data points represent aliquots of ca. 50 and $150 \mathrm{mg}$ that deviate towards older ages, in the range of $1500 \mathrm{Ma}$ (Fig. 8, Table 3). A diagram of ${ }^{187} \mathrm{Os} /{ }^{188}$ Os vs. $1 /{ }^{192} \mathrm{Os}$, using “common" ${ }^{192}$ Os rather than total Os (including radiogenic ingrowth of ${ }^{187} \mathrm{Os}$ ), enables a fair assessment of possible mixing between the Re-Os system in the host mineral and fluids interacting with the host mineral after its precipitation (van Acken et al., 2014). The isochronous behavior of the four data points for aliquots of at least $200 \mathrm{mg}$, combined with the absence of a linear correlation in ${ }^{187} \mathrm{Os} /{ }^{188} \mathrm{Os}-1 /{ }^{192}$ Os space (Figs. 8 and 11), indicate that the Re-Os systematics were preserved in cobaltite at the Haynes-Stellite deposit, and hence that the late Mesoproterozoic (ca. $1349 \mathrm{Ma}$ ) age is valid and suitable for interpretation. A minimum aliquot size of 200 mg appears necessary to obtain reproducible Re-Os data for cobaltite from the Haynes-Stellite deposit.

The fine-grained cobaltite from the Idaho zone has an extremely uniform chemical composition independent of the mineral fraction (i.e., M 0.3 and M 0.6; Fig. 7 and Table 2). In both fractions, in particular M 0.6, cobaltite shows evidence of recrystallization of formerly very fine-grained $(<10 \mu \mathrm{m})$ cobaltite that coalesced together to produce coarser-grained (ca. $20 \mu \mathrm{m}$ ) cobaltite embedded in silicates \pm xenotime (Fig. 6h). The isochronous behavior of the seven data points for the Idaho zone with lowuncertainty ellipses, and the lack of linear correlation in ${ }^{187} \mathrm{Os} /{ }^{188} \mathrm{Os}-1 /{ }^{192} \mathrm{Os}$ space (Figs. 7 and 11 ), imply that the $1132 \pm 240 \mathrm{Ma}$ isochron age is meaningful. Taken the recrystallization textures and the validity of the Re-Os age together, our approach considers that this age for the Idaho zone is reflecting a 
recrystallization event of a proto-ore. This proto-ore might have originally formed at the same time as the Haynes-Stellite deposit.

In the Chicago zone, the alternating bands of close-packed fine-grained and coarse-grained massive cobaltite (Figs. 4b, 6) have been interpreted by Bookstrom et al. (2016) as a product of the recrystallization of pre-existing cobaltite mineralization in response to Cretaceous metamorphism that produced cross-aligned cobaltite fabrics as those shown in Fig. 4b. Our results support this interpretation. This cobaltite, metamorphosed to middle- to upper-greenschist facies, has the lowest Co and the highest $\mathrm{Ni}$ contents of samples analyzed in this study (Fig. 3, Table 2). We suggest that Co was lost from cobaltite but retained in the surrounding rock in other minerals during prograde metamorphism. This mechanism would explain the Co contents of ore-enclosing hornfels-like biotitite in the Blackbird area (i.e., 19 ppm Co; Connor, 1991; Bookstrom et al., 2016). In this interpretation, these rocks are not the source of ore metals but became rather enriched in metals as a result of metal redistribution from ore during metamorphism. A similar interpretation has been used to explain a comparable pattern for Co contents of pyrite and other sulfide minerals within unmetamorphosed to amphibolites-facies graywacke in the Otago and Alpine schists of New Zealand (Pitcairn et al., 2010). These authors observed that the prograde metamorphic breakdown of pyrite to pyrrhotite was accompanied by a redistribution of Co and $\mathrm{Ni}$ that remained in the rock and were incorporated into sulfide minerals other than pyrite. Whereas Co was probably lost to biotite hornfels during prograde metamorphism in the Blackbird district, Ni was preferentially enriched in cobaltite in the Chicago zone. Although it is tempting to link this Ni-enrichment to the presence of pyrrhotite that was observed in other samples from the Chicago zone (cf. Bookstrom et al., 2016), no pyrrhotite inclusions were observed in cobaltite from the studied sample.

The significant scatter of the Re-Os data in the ${ }^{187} \mathrm{Re} /{ }^{188} \mathrm{Os}-{ }^{187} \mathrm{Os} /{ }^{188} \mathrm{Os}$ space for the Chicago zone sample is logical for cobaltite that recrystallized during metamorphism and underwent disturbance of the Re-Os chronometer (Fig. 8). In addition, disturbance of the chronometer during metamorphism would be expected to result in mixed signatures of the metamorphic fluid and the primary Re-Os budget in cobaltite. Some degree of mixing is observed in the pseudo-linear trend of the Chicago zone data points in 
${ }^{187} \mathrm{Os} /{ }^{188} \mathrm{Os}-1 /{ }^{192} \mathrm{Os}$ space (labeled "CH-x" in Fig. 11, green ellipse). Mixing with the primary Re-Os budget of cobaltite may have involved metamorphic fluids of Grenvillian and/or Cretaceous age but other types of fluids infiltrating after cobaltite formation are possible. Anyhow, the absence of isochronous behavior of the data and evidence of mixing with fluids after cobaltite formation suggest significant disturbance of the Re-Os system that cannot be used to determine the timing of this disturbance (Figs. 8 and 11).

\subsection{From Middle Mesoproterozoic cobaltite mineralization to Grenvillian and Cordilleran metamorphic overprints}

A summary of events from the initial formation of the Belt Basin in the early Mesoproterozoic to compressive tectonics of the Late Jurassic to Late Cretaceous Cordilleran fold-and-thrust belt is shown in Fig. 12. In the discussion below, we review how the new Re-Os geochronological data compares with existing time constraints on relevant regional geological events.

The cobaltite Re-Os age of $1349 \pm 76$ Ma for the Haynes-Stellite deposit is consistent (within a relatively large uncertainty of about $\pm 5.6 \%$, due primarily to the limited range of ${ }^{187} \mathrm{Re} /{ }^{188} \mathrm{Os}$ and ${ }^{187} \mathrm{Os} /{ }^{188}$ Os ratios; Fig. 8, Table 3), with existing constraints for the age of the host rock and the age of geographically associated plutonism. The Haynes-Stellite Re-Os age is younger than the maximum age of the host sedimentary unit (Gunsight Formation, Fig. 2; Bookstrom et al., 2016), as given by the age of the youngest SHRIMP U-Pb detrital zircon population peak (1409 $\pm 10 \mathrm{Ma}$; Aleinikoff et al., 2012). In addition, this cobaltite age correlates broadly with the age of emplacement of the nearby bimodal gabbrogranite suite of plutons (ca. 1383 and 1359 Ma; Anderson and Davis, 1995; Evans et al., 2000; Aleinikoff et al., 2012), considered to be intruded during the East Kootenay orogeny (ca. 1379 to 1325 Ma; Zirakparvar et al., 2010, and references therein). The timing for cobaltite mineralization at ca. $1349 \mathrm{Ma}$ supports the proposal of Slack (2012) that sulfide mineralization occurred in connection with intrusion of the Big Deer Creek granite dated at $1377 \pm 4$ Ma (Aleinikoff et al., 2012). This granite is presently found in the Haynes-Stellite structural block (Fig. 3) and intruded into the host rocks to the Haynes-Stellite 
deposit. Aleinikoff et al. (2012) and Slack (2012) convincingly argued for a genetic link of xenotime precipitation in the Apple Creek Formation and emplacement of the Big Deer Creek granite, a model strengthened by the presence of an allanite prospect in pegmatite within this granite (Slack, 2012, Fig. 1). Of particular interest is the oldest generation of xenotime dated at $1370 \pm 4$ Ma that locally forms inclusions in cobaltite (e.g., Merle deposit, Fig. 3; Aleinikoff et al., 2012), suggesting that cobaltite in the Merle deposit is younger than ca. 1370 Ma. Our ca. 1349 Ma Re-Os age, although not based on cobaltite with xenotime inclusions dated at ca. $1370 \mathrm{Ma}$ as at Merle, suggests that Co-sulfide deposition occurred shortly after a phase of REE-Y mineralization in connection with emplacement of the Big Deer Creek granite. Slack (2012) noted the close textural association of cobaltite and xenotime in many samples from the Blackbird district. This cobaltite age agrees with bracketing of the formation of the quartz-tourmalinecobaltite breccia between 1370 and $1320 \mathrm{Ma}$, as proposed by Bookstrom et al. (2016) in their synthesis of the geologic history of the Blackbird mine area based on relative age relationships and available isotope age determinations on gangue minerals. In the light of this independent data and our new Re-Os age of ca. $1349 \mathrm{Ma}$, we propose that the Haynes-Stellite cobaltite mineralization formed in the middle Mesoproterozoic time. The Re-Os isotopic system closed in this mineral at that time without being disturbed or reset by Grenvillian metamorphism (ca. 1190 to $1006 \mathrm{Ma}$ ), nor by later tectonism, metamorphism, and plutonism associated with Cordilleran orogenesis in Late Jurassic to Late Cretaceous time (ca. 151-83 Ma; Bookstrom et al., 2016, and references therein).

The imprecise isochron age for cobaltite in the Idaho zone $(1132 \pm 240 \mathrm{Ma}, \pm 21 \%)$ overlaps within uncertainty the Re-Os age of cobaltite mineralization at Haynes-Stellite. However, the interpretation that this age records a younger event for the Idaho zone, distinct from that of the HaynesStellite deposit, is suggested by three pieces of evidence: (1) cobaltite in the Idaho zone has at least 3 times less Re than cobaltite at Haynes-Stellite (Table 3), (2) the data points for each of these deposits define separate clusters in ${ }^{187} \mathrm{Re} /{ }^{188} \mathrm{Os}-{ }^{187} \mathrm{Os} /{ }^{188} \mathrm{Os}$ space (Fig. 8), and, (3) the initial ${ }^{187} \mathrm{Os} /{ }^{188} \mathrm{Os}$ ratios for cobaltite in these deposits are distinct within error (Figs. 9 and 10). In addition, Bookstrom et al. (2016) provided strong evidence for a younger age for the Idaho zone than for the Haynes-Stellite deposit. Unlike 
the quartz-tourmaline-cobaltite breccia at Haynes-Stellite, the quartz-tourmaline-breccia of the Idaho zone parallels the axial planar $S_{2}$ cleavage of $F_{2}$ folds and is coeval with a phase of cobaltite-xenotime precipitation bracketed at 1058 to $990 \mathrm{Ma}$. Our Re-Os age for the Idaho zone, albeit imprecise, overlaps with the timing proposed by Bookstrom et al. (2016). This corresponds to the time span of a regional deformation and metamorphic event in western Laurentia (Zirakparvar et al., 2010; Vervoort et al., 2015), which overlaps with the timing of the classic Grenvillian orogeny. A few hundred kilometers to the north in the Coeur d'Alene, Idaho mining district, the main ore stage silver mineralization in the Galena mine yielded a Re-Os arsenopyrite age of ca. 1220 Ma, i.e., broadly Grenvillian (Arkadakskiy et al., 2009). Other evidence of hydrothermal mineral precipitation (or recrystallization) of Grenvillian age in the BeltPurcell Basin was reported by Slack et al. (2008) for polycrase and titanite in the Sullivan Pb-Zn-Ag deposit at ca. 1150-1050 Ma, and by Aleinikoff et al. (2015) for xenotime at ca. 1160-1050 Ma during sub-greenschist-facies temperatures in the upper section of the Belt Supergroup. Given the relationship in the Idaho zone between the quartz-tourmaline-breccia and the local fold axial planar cleavage (Bookstrom et al., 2016), we suggest that ore in the Idaho zone was originally deposited in the middle Mesoproterozoic (as in the case of the Haynes-Stellite quartz-tourmaline-cobaltite breccias) but was affected by dynamothermal events during the Grenvillian orogeny. The Re-Os isotopic system in cobaltite in the Idaho zone was thus reset to yield a Grenvillian, yet, highly imprecise, age. The uncertainty in this age is primarily due to the relatively low Re and radiogenic ${ }^{187}$ Os contents. If the Idaho zone originally formed at the same time as the Haynes-Stellite deposit, then Re (and Os) would have been lost during Grenvillian resetting, thereby explaining the lower Re and Os contents in cobaltite from the Idaho zone and its much younger late Mesoproterozoic age. The Grenvillian age recorded by the Re-Os isotopic system in the Idaho zone was preserved through middle- to upper-greenschist facies metamorphism in Cretaceous time in the Blackbird domain (Fig. 3).

Cobaltite from the Chicago Zone could not be dated by the isochron method and mixing between the original Re-Os budget of cobaltite and a later fluid is a suggested explanation. Yet, the highly radiogenic ${ }^{187} \mathrm{Re} /{ }^{188} \mathrm{Os}$ and ${ }^{187} \mathrm{Os} /{ }^{188} \mathrm{Os}$ ratios for this zone, in the range of those encountered at Haynes- 
Stellite and in the Idaho zone, favor a middle Mesoproterozoic proto-ore in which the Re-Os isotopic system was severely disturbed by post-mineralization events. Given the compelling evidence of recrystallization of most cobaltite during Cretaceous metamorphism (Aleinikoff et al., 2012; Slack, 2012), we suggest that the scatter in Re-Os data (Fig. 8) observed in recrystallized, fine- to coarse-grained massive cobaltite (Fig. 4 and Fig. 6), is the result of Cretaceous dynamothermal events and compressive tectonics (i.e., shear zone that hosts the Chicago zone). According to Eiseman (1988), Cretaceous metamorphism in the garnet zone in the Blackbird district reached 400 to $520^{\circ} \mathrm{C}$. The garnet zone is located less than $100 \mathrm{~m}$ to the north-east of the shear zone-hosted Chicago zone (Slack, 2012). It is possible, yet tentative, that the tectonic configuration of the Chicago zone concurred to thermal conditions close to the temperature range for the garnet zone of metamorphism in Cretaceous time. In this approach, temperatures above $400^{\circ} \mathrm{C}$ would be higher than the closure temperature for the Re-Os isotopic system in cobaltite that would need to be $\leq 400^{\circ} \mathrm{C}$.

In summary, our new Re-Os ages supported by a number of geologic constraints discount the possibility by Lund et al. (2011) of formation of $\mathrm{Cu}-\mathrm{Co} \pm \mathrm{Au}$ deposits in the ICB during Late Cretaceous compressional deformation. These authors presented a model that was based on the study of a series of structurally-controlled vein and alteration systems, and invoked wholly Cretaceous $\mathrm{Cu}-\mathrm{Co} \pm \mathrm{Au}$ mineralization. By contrast to the approach by Lund et al. (2011), our sequence of mineralizing events applies to tourmalinized breccia bodies and disseminated to semi-massive/massive layered ores in the ICB. Our model is based on the compelling evidence of the middle Mesoproterozoic Re-Os (1349 \pm 76 Ma) age for cobaltite in the Haynes-Stellite deposit. The similarities of the Haynes-Stellite deposit with the main Blackbird district (e.g., Idaho, Chicago, Merle zones), in terms of mineralogy (e.g., locally abundant tourmaline and xenotime with cobaltite), geochemistry (e.g., locally high Y and P), and isotopes (i.e., boron), as emphasized by Slack (2012), further and strongly support an original middle Mesoproterozoic age for essentially all of $\mathrm{Co}-\mathrm{Cu}-\mathrm{Au}$ concentrations in the region with metals derived from Precambrian rocks in the Laurentia basement. Then, without any further introduction of metals but rather the local recycling of the metal budget, cobaltite was affected by dynamothermal events during the 
Grenvillian orogeny (e.g., the Idaho zone) and/or Cretaceous deformation and metamorphism during the Cordilleran orogeny (e.g., the Chicago zone).

The origin of coarse-grained cobaltite associated with cobaltian arsenopyrite in chloritized biotite phyllite from the eastern ICB remains unknown. A highly tentative hypothesis would consider that the small high-grade Black Pine deposit (1.0 Mt at $4.5 \mathrm{wt} \%, 0.08 \mathrm{wt} \% \mathrm{Co}$, and $1.03 \mathrm{~g} / \mathrm{t} \mathrm{Au}$; Johnson et al., 1998) is a by-product of deformation and metamorphism with re-deposition of metals originally contained in Mesoproterozoic cobaltite ores of the Blackbird area. The mineral chemistry of cobaltite at Black Pine is the richest in cobalt in the current study and is devoid of Ni. Considering our interpretation for the Chicago zone that cobalt was released during Cretaceous metamorphism while Ni was proportionally enriched, cobalt would have been re-deposited elsewhere, i.e., possibly towards the distal Black Pine site, where temperature and pressure levels were lower as indicated by lower metamorphic grade. In addition to enriching in cobalt the ore-enclosing hornfels-like biotitite in the Blackbird area, it is possible that (Cretaceous?) metamorphism caused the formation of small high-grade deposit in NW-striking northwest and steeply NE-dipping strata like Black Pine. However, this scenario is highly unlikely as it required transport of Co for ca. $15 \mathrm{~km}$. Relevant studies elsewhere have documented the remobilization and transport of various components in metamorphosed deposits in the order of meters to tens of meters, but not tens of kilometers (Marshall et al., 2000; Corriveau and Spry, 2014, and references therein). A more probable scenario would consider that the Black Pine deposit initially formed in middle Mesoproterozoic time, and Co was redistributed elsewhere in the deposit (e.g., in cobaltite in the lower level Cu-rich zone of the Black Pine deposit) or nearby wall rocks during subsequent deformation and metamorphic events.

\subsection{Preferred genetic model for Mesoproterozoic cobaltite mineralization}

Considering the new Re-Os ages that indicate primary cobaltite mineralization in middle Mesoproterozoic time during the East Kootenay orogeny with reworking during the Grenvillian orogeny and/or the Cordilleran orogenies (Fig. 12), we propose a refined genetic model for cobaltite mineralization in the ICB. In contrast to a trend in modern geology in which ore deposits are classified into "boxes" with 
acronyms that often get misused, we choose to adopt a purely descriptive approach by synthesizing existing literature data and new Re-Os data within the geologic framework of the East Kootenay orogeny, followed by regional metamorphism in Grenvillian time, and by Cordilleran metamorphism, deformation, and plutonism in Late Jurassic to Late Cretaceous time. Any attempt to classify these deposits according to deposit types (e.g., IOCG, Iron Oxide Copper-Gold) should, therefore, "see through" metamorphism, and, take into account the established reaction of sulfide (e.g., pyrite) destabilization and $\mathrm{H}_{2} \mathrm{~S}$ devolatilization during prograde metamorphism.

As originally proposed by Slack (2012), cobaltite deposits in the ICB are indeed an expression of multistage hydrothermal mineralization related to a magmatic-hydrothermal system. Although the middle Mesoproterozoic ca. 1349 Ma Re-Os age for cobaltite mineralization applies strictly to the Haynes-Stellite tourmalinized breccias, key mineralogical and geochemical ties exist between mineralization of these breccias and the strata-bound sulfide deposits of the Blackbird district (Slack, 2012), and include: (1) the presence of abundant xenotime with cobaltite locally in both deposit types (Slack, 2012; our Fig. 6), and (2) similar boron isotope values $\left(\delta^{11} \mathrm{~B}\right)$ of -6.9 to $+3.2 \%$ determined for the breccia-hosted tourmalines and those within the strata-bound sulfide deposits such as in the Idaho zone (Trumbull et al., 2011; Slack, 2012). Hence, we propose that all of the $\mathrm{Co}-\mathrm{Cu}-\mathrm{Au}$ sulfide deposits were produced as part of an epigenetic $\mathrm{Co}-\mathrm{Cu}-\mathrm{Au}-\mathrm{Bi}-\mathrm{Y}-\mathrm{REE}$ mineralizing system linked to the emplacement of a ca. 1383 to $1359 \mathrm{Ma}$ suite of bimodal gabbro-granite intrusions, in particular the Big Deer Creek granite dated at $1377 \pm 4 \mathrm{Ma}$ (Aleinikoff et al., 2012; Slack, 2012). This mineralizing system would have deposited first Y, REEs, and Be-bearing minerals (xenotime, gadolinite-(Y)) at $1370 \pm 4$ Ma (Slack, 2012; Aleinikoff et al., 2012). The second phase of mineralization precipitated cobaltite, and possibly, by extension, the $\mathrm{Cu}$-sulfides. Given the fact that cobaltite mineralization clearly occurred long before Cretaceous metamorphism, a valid genetic model must see through the effects of metamorphism on the rocks and minerals in order to understand the conditions at the time of mineralization, by documenting the origin, composition, and source of the three key ingredients for mineralization: (1) hydrothermal fluids, (2) sulfur, and (3) metals. 
Landis and Hofstra (2012) proposed that the hydrothermal fluid trapped in gangue quartz associated with cobaltite mineralization in the Blackbird district was a mixture of evaporated seawater and subordinate magmatic fluid. Trumbull et al. (2011) invoked hydrothermal fluids at a formational temperature of $300^{\circ} \mathrm{C}$ and boron isotopic composition of -7 to $3 \%$ that originated from marine carbonates and/or evaporitic marine borates, chemogenic sediments that are currently found in the form of scapolitetourmaline beds that occur in the Yellowjacket and Apple Creek Formations (Fig. 1A; Tysdal and Desborough, 1997; Tysdal et al., 2003). The presence of evaporitic marine borates is compatible with the equatorial paleolatitudes that existed during early Mesoproterozoic deposition of the Belt Supergroup (i.e., host rocks of the ICB; Landis and Hofstra, 2012, and references therein). We suggest that intrusion of the Big Deer Creek granite at ca. 1377 Ma mobilized these evaporitic fluids, which then mixed with magmatic-related fluids as indicated by mantle-derived ${ }^{3} \mathrm{He}$ and fluorine-derived ${ }^{22} \mathrm{Ne}$ within volatiles trapped in the same gangue quartz (Landis and Hofstra, 2012).

The initial ${ }^{187} \mathrm{Os} /{ }^{188} \mathrm{Os}$ ratio determined through isochron regression reflects the origin of bulk Os incorporated in a mineral at the time of precipitation, prior to ingrowth of radiogenic ${ }^{187}$ Os below the blocking temperature of the Re-Os system in the given mineral (e.g., Walker et al., 1991). By extension, the initial ratio may be used to trace the source of metals and cobalt in samples from the present case study. The extremely high initial ${ }^{187} \mathrm{Os} /{ }^{188} \mathrm{Os}$ ratio for the Haynes-Stellite deposit $(4.7 \pm 2.2)$ points to Archean and Paleoproterozoic source rocks from which Os (and by inference other metals) were derived. The ICB in the Lehmi sub-basin is underlain by a NE-SW-striking corridor of Laurentian basement rocks of the Great Falls tectonic zone that is sandwiched between the 3.2-2.8 Ga Medicine Hat block in the northwest and the >2.5 Ga Wyoming craton in the southeast (Fig. 1B; Vervoort et al., 2015; Wang, 2015; Kilian et al., 2016). The Great Falls tectonic zone comprises a Paleoproterozoic oceanic island-arc terrane that is in turn underlain by a very thick mafic body interpreted from seismic data (Foster et al., 2006). These Paleoproterozoic \pm Archean rocks, with overall mafic affinity, appear to be sound candidates to have supplied metals like Co for mineralization in the region. It is also a possibility that these Paleoproterozoic \pm Archean rocks had the necessary $\mathrm{Pb}$ isotopic composition to explain the radiogenic $\mathrm{Pb}$ 
composition found in the $\mathrm{Co}-\mathrm{Cu}-\mathrm{Au}$ ores by Panneerselvam et al. (2012). Radiogenic $\mathrm{Pb}$ would have been produced in these rocks between the time of their formation in the Archean and Paleoproterozoic and the time of the magmatic-hydrothermal event producing Co mineralization at ca. 1370-1350 Ma.

Arsenopyrite in the Galena mine from the Coeur d'Alene mining district a few hundred kilometers to the north has a similarly high initial ${ }^{187} \mathrm{Os} /{ }^{188}$ Os ratio of ca. 6 . Arsenopyrite that accompanies silver mineralization in the Galena deposit is younger (ca. 1220 Ma; Arkadakskiy et al., 2009) than the cobaltite mineralization at Haynes-Stellite. However, their similar range of initial ratios suggest derivation of metals from the same Paleoproterozoic to Archean rocks for mineralization in the Coeur d'Alene district, or possibly from older (ca. 1400 to $1500 \mathrm{Ma}$ ) ore deposits such as the Sullivan deposit in southeastern British Columbia (Fleck et al., 2002) in which metals may have been mobilized from the same Precambrian rocks.

Our interpretation is compatible with the uniform sulfur isotope values of cobaltite throughout the Blackbird district $(8.0 \pm 0.4 \%$ ) that were attributed by Johnson et al. (2012) to sulfur being sourced from deep, crustal, highly metamorphosed \pm magmatic rocks. Sulfur isotopic homogenization would have occurred during transport of possibly aqueous $\mathrm{H}_{2} \mathrm{~S}$ in the mixed hydrothermal fluids described above (Johnson et al., 2012; this study). Thus, considering that this proposed mixture of magmatic- and evaporated-seawater-derived hydrothermal fluids transported both metals and reduced sulfur, the only viable precipitation mechanism for sulfides is cooling, as originally proposed by Johnson et al. (2012). The biotitite zones in the Blackbird district (up to $1.87 \mathrm{wt} . \% \mathrm{Cl}$ in biotite) that are spatially and paragenetically associated with sulfide mineralization would thus represent metamorphosed alteration zones in which $\mathrm{Fe}$ - and $\mathrm{Cl}$-rich hydrothermal fluids reacted with aluminous clastic sediments to form abundant Cl-rich Fe biotite (Slack, 2012). Both hydrothermal alteration envelopes and sulfides were deformed during Cretaceous tectono-thermal events that produced the biotitites.

Following primary cobaltite mineralization in middle Mesoproterozoic time at ca. 1349 Ma, cobaltite was locally remobilized along $S_{2}$ cleavages during the Grenvillian orogeny at ca. $1132 \pm 240 \mathrm{Ma}$, as in the quartz-tourmaline-cobaltite breccia of the Idaho zone (Fig. 12). Remobilization of pre-existing 
middle Mesoproterozoic cobaltite with a high initial ${ }^{187} \mathrm{Os} /{ }^{188} \mathrm{Os}$ ratio of ca. 5 is a preferred interpretation that explains cobaltite mineralization in the Idaho zone with an initial ratio at ca. 9 and much lower Re contents than those in older cobaltite at Haynes-Stellite (Fig. 9). Finally, cobaltite was recrystallized and locally remobilized during Cretaceous metamorphism (Fig. 12; Bookstrom et al., 2007; Aleinikoff et al., 2012; Slack, 2012), in particular, in the form of recrystallized, fine- to coarse-grained massive cobaltite in the shear zone-hosted Chicago zone.

\section{Conclusions}

In the present study, we constrain for the first time the Re-Os systematics in cobaltite and report ReOs ages for cobaltite mineralization in two of the four studied deposits hosted by metasedimentary rocks of the ICB (i.e., Haynes-Stellite deposit, Chicago and Idaho zones of the Blackbird deposit, Black Pine prospect). Key results of our work are fourfold:

1. Variably magnetic fractions of cobaltite in the ICB have low Re and total Os contents (ca. 0.4-4 ppb and 14-64 ppt, respectively) but elevated ${ }^{187} \mathrm{Re} /{ }^{188} \mathrm{Os}(600-1800)$ and highly radiogenic ${ }^{187} \mathrm{Os} /{ }^{188}$ Os (17-45) ratios. Cobaltite from the Black Pine prospect has insufficient Re concentrations ( $<0.3 \mathrm{ppb})$ to produce reliable Re-Os isotopic data. In contrast, Re-Os data for cobaltite from the quartz-tourmaline-cobaltite breccia at the Haynes-Stellite deposit are accurate and reproducible, implying the need for a minimum aliquot size of $200 \mathrm{mg}$ whereas data for cobaltite from the quartz-tourmaline-cobaltite breccia of the Idaho zone require a minimum aliquot size of $150 \mathrm{mg}$.

2. Re-Os systematics in cobaltite from the Haynes-Stellite deposit and at the Idaho zone are preserved and Re-Os data are successfully regressed using the isochron approach. In contrast, the Re-Os systematics of cobaltite in the Chicago zone are disturbed, and a linear array of mixing with post-depositional fluids is identified in ${ }^{187} \mathrm{Os} /{ }^{188}$ Os vs. $1 /{ }^{192}$ Os space. Cobaltite was primarily deposited in the Haynes Stellite deposit at $1349 \pm 76$ Ma and was preceded by REE-Y-mineral 
precipitation at ca. $1370 \mathrm{Ma}$, in connection with the emplacement of the Big Deer Creek granite at ca. $1377 \mathrm{Ma}$ as part of a suite of bimodal magmatism between ca. 1383 and 1359 Ma (Aleinikoff et al., 2012). We propose that the Re-Os age of $1132 \pm 240$ Ma for cobaltite in the quartztourmaline breccia in the Idaho zone plus consideration of other geological and structural constraints (Bookstrom et al., 2007, 2016), records a remobilization phase of pre-existing cobaltite mineralization along cleavages and folds during the 1190-1006 Ma Grenvillian orogeny.

3. Cobaltite in the ICB initially formed at ca. 1349 Ma upon cooling at an inferred temperature of $\leq 300^{\circ} \mathrm{C}$ from a mixture of Mesoproterozoic evaporitic brines and magmatic-hydrothermal fluids that carried both metals and reduced sulfur. The extremely high initial Os ratio of $4.7 \pm 2.2$ derived from regression of the Re-Os data for the Haynes-Stellite deposit is used a tracer to identify the source of metals. The most likely scenario involves metal derivation from lower crustal mafic source rocks of probable Archean age, overlain by oceanic island-arc rocks of Paleoproterozoic age. These two rock suites are tectonically interlayered with Archean rocks of the Wyoming Province, within the collisional Great Falls tectonic zone, which projects beneath the ICB. This scenario is compatible with the sulfur isotopic composition of cobaltite $(+8.0 \pm$ $0.4 \%$ ) reflecting a reduced sulfur source from deep, crustal, and highly metamorphosed rocks (Johnson et al., 2012).

4. The Re-Os isotopic system in cobaltite from the Chicago zone, located in a shear-zone in a middle greenschist-facies metamorphic domain less than $100 \mathrm{~m}$ away from the garnet zone, was probably disturbed during Cretaceous metamorphism. A maximum closure temperature of $400^{\circ} \mathrm{C}$ is thus inferred for Re-Os in cobaltite. In contrast, cobaltite in the Haynes-Stellite deposit and the Idaho zone, which underwent lower to middle greenschist-facies metamorphism during the Cretaceous, preserves Mesoproterozoic age information delivered by the Re-Os isotope system.

\section{Acknowledgments}


This study was supported financially through a Swiss National Science Foundation (SNSF) Early Postdoc Mobility Grant awarded to N.J. Saintilan (NJS; P2GEP2_162075), and, an NSERC Discovery Grant awarded to R.A. Creaser (RAC). We are indebted to George Lusher and Brett Riggan (Blackbird Mine Group) and Bill Scales and George King (Formation Metals Inc.) for permission to visit, study, and collect samples within the gated Blackbird mine area. NJS and RAC thank the staff at the USGS Office in Spokane for welcoming them during two short visits. NJS also thanks Andrew Locock (University of Alberta) for his help and technical support in acquisition of electron microprobe data. We also wish to thank Stephen E. Box (USGS) and John F. Slack (USGS, Emeritus) who were both involved in the internal USGS review process while S.E. Box was also designated as reviewer by Editor F. Pirajno. The reviewers provided constructive comments and suggestions that concurred to clarify several aspects of the manuscript and sharpen our interpretations. We are grateful to Editor F. Pirajno for the overall edition work during the review process.

\section{References}

Ahmed, H.A., Arai, S., and Ikenne, M., 2009. Mineralogy and paragenesis of the Co-Ni arsenide ores of Bou Azzer, Anti-Atlas, Morocco. Econ. Geol. 104, 249-266.

Aleinikoff, J.N., Slack, J.F., Lund, K., Evans, K.V., Fanning, C.M., Mazdab, F.K., Wooden, J.L., and Pillers, R.M., 2012. Constraints on the timing of $\mathrm{Co}-\mathrm{Cu}+\mathrm{Au}$ mineralization in the Blackbird district, Idaho, using SHRIMP U$\mathrm{Pb}$ ages of monazite and xenotime plus zircon ages of related Mesoproterozoic orthogneisses and metasedimentary rocks. Econ. Geol. 107, 1143-1175.

Aleinikoff, J.N., Lund, K., and Fanning, M.C., 2015. SHRIMP U-Pb and REE data pertaining to the origins of xenotime in Belt Supergroup rocks: evidence for ages of deposition, hydrothermal alteration, and metamorphism. Can. J. Earth Sci. 52, 722-745.

Anderson, A.L., 1947. Cobalt mineralization in the Blackbird district, Lemhi County, Idaho. Econ. Geol. 42, $22-46$. Anderson, H.E., and Davis, D.W., 1995. U-Pb geochronology of the Moyie sills, Purcell Supergroup, southeastern British Columbia: Implications for Mesoproterozoic geological history of the Purcell (Belt) Basin. Can. J. Earth Sc. 32, 1180-1193. 
Arkadakskiy, S.V., Creaser, R.A., Richards, J.P., Hnatyshin, D., and Hardy, Lisa, 2009. Re-Os dating of arsenopyrite from the Galena mine - evidence for Mesoproterozoic age of the Ag- $\mathrm{Pb}-\mathrm{Zn}$ mineralization in the Coeur d'Alène district, Idaho. Geol. Soc. Amer. Abs. Pgms. 26, 1.

Armstrong, J.T., 1988. Quantitative analysis of silicates and oxide minerals: Comparison of Monte-Carlo, ZAF and phi-rho-z procedures, in: Newbury, D.E. (Ed.), Microbeam analysis, San Francisco Press, San Francisco, pp 239-246.

Beziat, D., Monchoux, P., and Tollon, F., 1996. Cobaltite-gersdorffite solid solution as a primary magmatic phase in spessartite, Lacaune area, Montagne Noire, France. Can. Miner. 34, 503-512.

Bookstrom, A.A., 2013. The Idaho cobalt belt. Northwest Geology 42, 149-162.

Bookstrom, A.A., Johnson, C.A., Landis, G.P., and Frost, T.P., 2007. Blackbird Fe-Cu-Co-Au-REE deposits: U.S. Geological Survey Open-File Report 2007-1280-B, 13-20, available online at http://pubs.usgsgov/of/2007/1280

Bookstrom, A.A., 2013. The Idaho cobalt belt. Northwest Geology 42, 149-162.

Bookstrom, A.A., Box, S.E., Cossette, P.M., Frost, T.P., Gillerman, V.S., King, G.R., and Zirakparvar, N.A., 2016. Geologic history of the Blackbird Co-Cu district in the Lemhi sub-basin of the Belt-Purcell Basin, in: MacLean, J.S., and Sears, J.W. (Eds.), Belt Basin: Window to Mesoproterozoic Earth: Geol. Soc. Amer. Sp. Paper 522, available open access on www.gsapubs.org.

Box, S.E., Bookstrom, A.A., and Anderson, R.G., 2012. Origins of mineral deposits, Belt-Purcell Basin, United States and Canada: An introduction. Econ. Geol. 107, 1081-1088.

Burmester, R.F., Lonn, J.D., Lewis, R.S., and McFaddan, M.D., 2013. Toward a grand unified theory for stratigraphy of the Lemhi sub-basin of the Belt Supergroup, in: Lewis, R.S., Garsjo, M.M., and Gibson, R.I. (Eds.), Belt Symposium V: Missoula, Montana, Tobacco Root Geol. Soc.: Northwest Geol. 42, 1-19.

Connor, J.J., 1991. Some geochemical features of the Blackbird and Jackass Zones of the Yellowjacket Formation (Middle Proterozoic) in east-central Idaho. U.S. Geological Survey Open-File Report 91-259A, 25p.

Cook, N.J., Ciobanu, C.L., Meria, D., Silcock, D., and Wade, B., 2013. Arsenopyrite-pyrite association in an orogenic gold ore: Tracing mineralization history from texture and trace elements. Econ. Geol. 108, 1273-1283. Corriveau, L., and Spry, P.G., 2014. Metamorphosed hydrothermal ore deposits, in: Scott, S. (Ed.), Treatise on geochem. 13, 175-194. 
Creaser, R.A., Papanastassiou, D.A., Wasserburg, G.J., 1991. Negative thermal ion mass spectrometry of osmium, rhenium and iridium. Geochim. Cosmochim. Acta 55, 397-401.

Davies, T., Richards, J.P., Creaser, R.A., Heaman, L.M., Chacko, T., Simonetti, A., Williamson, J., and McDonald, D.W., 2010. Paleoproterozoic age relationships in the Three Bluffs Archean iron formation-hosted gold deposit, Committee Bay Greenstone Belt, Nunavut, Canada. Expl. Min. Geol. 19, 55-80.

Donovan, J.J., Snyder, D.A., and Rivers, M.L., 1993. An improved interference correction for trace element analysis. Microbeam Anal. 2, 23-28.

Eiseman, H.H.,1988. Ore geology of the Sunshine cobalt deposit, Blackbird mining district, Idaho (M. S. Thesis): Golden, Colorado, Colorado School of Mines, 191 p.

Evans, K.V., 1984. Ordovician plutonism in east-central Idaho: Variation on a Canadian theme. Geol. Soc. Amer. Abs. Pgms. 16, 504.

Evans, K.V., and Green, G.N., 2003. Geologic map of the Salmon National Forest and vicinity, east-central Idaho: U.S. Geological Survey Geologic Investigations Series Map I-2765, 2 sheets, scale 1:100,000, pamphlet, 19 p.

Evans, K.V., and Zartman, R.E., 1990. U-Th-Pb and Rb-Sr geochronology of Middle Proterozoic granite and augen gneiss, Salmon River Mountains, east-central Idaho: Geol. Soc. Amer. Bul. 102, 63-73.

Evans, K.V., Aleinikoff, J.N., Obradovich, J.D., and Fanning M.C., 2000. SHRIMP U-Pb geochronology of volvanic rocks, Belt Supergroup, western Montana: evidence for rapid deposition of sedimentary strata. Can. J. Earth. Sci. $37,1287-1300$.

Fleck, R.J., Criss, R.E., Eaton, G.F., Clealand, R.W., Wavra, C.S., and Bond, W.D., 2002. Age and origin of base and precious metal veins of the Coeur d'Alène mining district, Idaho. Econ. Geol. 97, 23-42.

Foster, D.A., Mueller, P.A., Mogk, D.W., Wooden, J.L., and Vogl, J.J., 2006. Proterozoic evolution of the western margin of the Wyoming craton: Implications for the tectonic and magmatic evolution of the northern Rocky Mountains. Can. J. Earth Sci. 43, 1601-1619.

Gasching, R.M., Vervoort, J.D., Lewis, R.S., and McClelland, W.C., 2010. Migrating magmatism in the northern US cordillera: in situ U-Pb geochronology of the Idaho batholith. Contrib. Mineral. Petrol. 159, 863-883.

Gillerman, V.S., 2008. Geochronology of iron oxide-copper-thorium-REE mineralization in Proterozoic rocks at Lemhi Pass, Idaho, and a comparison to copper-cobalt ores, Blackbird mining district, Idaho: Final Report to U.S. Geological Survey, Grant 06HQGR0170, 64 p., with Appendices A to D. 
Hnatyshin, D., Kontak, D.J., Turner, E.C., Creaser, R.A., Morden, R., and Stern, R.A., 2016. Geochronologic (ReOs) and fluid-chemical constraints on the formation of the Mesoproterozoic-hosted Nanisivik Zn-Pb deposit, Nunavut, Canada: Evidence for early diagenetic, low-temperature conditions of formation. Ore Geol. Rev. 79, 189-217.

Huston, D., Wygralak, A., Mernagh, T., Vandenberg, I.C., Crispe, A. J., Lambeck, A., Bagas, L., Cross, A., Fraser, G., Williams, N., Worden, K., and Meixner, T., 2007. Lode gold mineral systems of the Tanami Region, northern Australia. Mineral. Deposita 42, 175-204.

Jiang, S.-Y., Slack, J.F., and Palmer, M.R., 2000. Sm-Nd dating of the giant Sullivan Pb-Zn-Ag deposit, British Columbia. Geology 28, 751-754.

Johnson, C.A., Bookstrom, A.A., and Slack, J.F., 2012. Sulfur, carbon, hydrogen, and oxygen isotope geochemistry of the Idaho cobalt belt. Econ. Geol. 107, 1207-1221.

Johnson, R., Close, T., and McHugh, E., 1998. Mineral resource appraisal of the Salmon National Forest, Idaho: U.S. Geological Survey Open-File Report 98-478, p. 277, 7 pl.

Kilian, T.M., Chamberlain, K.R., Evans, D.A.D., Bleeker, W., and Cousens, B.L., 2016. Wyoming on the run Toward final Paleoproterozoic assembly of Laurentia. Geology 44, 863-866.

Landis, G.P., and Hofstra, A.H., 2012. Ore genesis constraints on the Idaho cobalt belt from fluid inclusion gas, noble gas isotope, and ion ratio analyses. Econ. Geol. 107, 1189-1205.

Lawrence, D.M., Treloar, P.J., Rankin, A.H., Harbidge, P., and Holliday, J., 2013. The geology and mineralogy of the Loulo mining district, Mali, West Africa: Evidence for two distinct styles of orogenic gold mineralization. Econ. Geol. 108, 199-227.

Link, P.K., Fanning, M.C., Lund, K.I., and Aleinikoff, J.N., 2007. Detrital zircon populations and provenance of Mesoproterozoic strata of east-central Idaho, U.S.A.: Correlation with Belt Supergroup of southwest Montana, in: Link, P.K., and Lewis, R.L. (Eds.), Proterozoic geology of western North America and Siberia. Society for Sedimentary Geology (SEPM) Spec. Pub. 86, 101-128.

Ludwig, K.R., 2011. User's manual for Isoplot 4.15: A geochronological toolkit for Microsoft Excel. Geochronology Center Berkeley, 4, 1-70. 
Lund, K., and Tysdal, R.G., 2007. Stratigraphic and structural setting of sediment-hosted Blackbird gold-cobaltcopper deposits, east-central Idaho, in: Link, P-K., and Lewis, R.L. (Eds.), Proterozoic geology of Western North America and Siberia: Society for Sedimentary Geology (SPEM) Sp. Pub. 86, 129-147.

Lund, K., Aleinikoff, J.N., Evans, K.V., du Bray, E.A., Dewitt, E.H., and Unruh, D.M., 2010, SHRIMP U-Pb dating of recurrent Cryogenian and Late Cambrian-Early Ordovician alkalic magmatism in central Idaho: implications for Rodinian rift tectonics: Geological Society of America Bulletin, v. 122, p. 430-453.

Lund, K., Tysdal, R.G., Evans, K.V., Kunk, M.J., and Pillers, R.M., 2011. Structural controls and evolution of gold-, silver-, and REE-bearing copper-cobalt ore deposits, Blackbird district, east-central Idaho — epigenetic origins. Econ. Geol. 106, 585-618.

Marshall, B., Vokes, F.M., and Larocque, A.C.L., 2000. Regional metamorphic remobilization: upgrading and formation of ore deposits. Rev. Econ. Geol. 11.1

Mikulski, S. Z., Markey, R. J., and Stein, H. J., 2005. Re-Os ages for auriferous sulfides from the gold deposits in the Kaczawa Mountains (SW Poland), in: Mao, J., and Bierlein, F.P. (Eds.), Mineral Deposit Research: Meeting the global challenge, Proceedings of Eighth Biennial SGA Meeting, Beijing, China, 18-21 August 2005, Springer Berlin Heidelberg, 793-796.

Morelli, R.M., Bell, C.C., Creaser, R.A., and Simonetti, A., 2010. Constraints on the genesis of gold mineralization at the Homestake gold deposit, Black Hills, South Dakota from rhenium-osmium sulfide geochronology. Mineral. Deposita 45, 461-480.

Mulder, J., Karlstrom, K., Jacqueline, A., Jones III, J.V., and Holland, M.E., 2016. The Mesoproterozoic sedimentary record of long-term Australian/Antarctic, Laurentian connections. Geol. Soc. Amer. Abs. Pgms 48, 7.

Nash, J.T., and Connor, J.J., 1993. Iron and chlorine as guides to concordant $\mathrm{Cu}-\mathrm{Co}-\mathrm{Au}$ deposits, Idaho cobalt belt. Mineral. Deposita 28, 99-106.

Nimis, P., Zaykov, V.V., Omenetto, P., Melekestseva, I., Yu, Tesalina, S.G., and Orgeval, J.-J., 2008. Peculiarities of some mafic-ultramafic- and ultramafic-hosted massive sulfide deposits from the Main Uralian Fault Zone, southern Urals. Ore Geol. Rev. 33, 49-69.

Nold, J.L., 1990. The Idaho cobalt belt, northwestern United States - A metamorphosed Proterozoic exhalative ore district: Mineral. Deposita 25, 163-168. 
O’Neill, J.M., 1993. The Great Falls tectonic zone, Montana-Idaho: An Early Proterozoic collisional orogeny beneath and south of the Belt Basin, in: Berg, R.B. (Ed.), Belt Symposium III, Butte, Montana: Montana Bureau of Mines and Geology Special Publication 112, 222-228.

O’Neil, J.M., Ruppel, E.T., and Lopez, D.A., 2007. Great Divide megashear, Montana, Idaho, and Washington - An intraplate crustal-scale shear zone recurrently active since the Mesoproterozoic, in: O’Neill, J.M. (Ed.), Metallogeny of Mesoproterozoic Sedimentary Rocks in Idaho and Montana - Studies by the Mineral Resources Program, U.S. Geological Survey, 2004-2007. U.S. Geological Survey Open-File Report 2007-1280-A, 3-10.

Panneerselvam, K., MacFarlane, A.W., and Salters, V.J.M., 2012. Reconnaissance lead isotope characteristics of the Blackbird deposit: Implications for the age and origin of cobalt-copper mineralization in the Idaho cobalt belt, USA. Econ. Geol. 107, 1177-1188.

Pitcairn, I.K., Teagle, D.A.H., Craw, D., Olivo, G.R., Kerrich, R., and Brewer, T.S., 2006. Sources of metals and fluids in orogenic gold deposits: Insights from the Otago and Alpine Schists, New Zealand. Econ. Geol. 101, 1525-1546.

Pitcairn, I.K., Olivo, G.R., Teagle, D.A.H., and Craw, D., 2010. Sulfide evolution during prograde metamorphism of the Otago and Alpine Schists, New Zealand. Can. Mineral. 48, 1267-1295.

Saintilan, N.J., Creaser, R.A., and Spry, P.G., 2017. Re-Os systematics of löllingite and arsenopyrite in granulite facies garnet rocks: Insights into the metamorphic evolution of the Broken Hill block during the Early Mesoproterozoic (New South Wales, Australia). Can. Mineral. (in press).

Shirey, S.B., and Walker, R.J., 1995. Carius tube digestions for low-blank rhenium-osmium analysis. Anal. Chem. $67,2136-2141$.

Sims, P.K., O’Neill, J.M., and Bankey, V., 2004. Precambrian basement geologic map of Montana - An interpretation of aeromagnetic anomalies. U.S. Geological Survey Sci. Invest. Map 2829.

Slack, J.F., 2006. High REE and Y concentrations in Co-Cu-Au ores of the Blackbird district, Idaho. Econ. Geol. And Bul. Soc. Econ. Geol. 101, 275-280.

Slack, J.F., 2012. Strata-bound Fe-Co-Cu-Au-Bi-Y-REE deposits of the Idaho Cobalt Belt: Multistage hydrothermal mineralization in a magmatic-related iron oxide copper-gold system. Econ. Geol. 107, 1089-1113.

Slack, J.F., 2013. Introduction, chapter 1, in: Slack, J.F. (Ed.), Descriptive and geoenvironmental model for cobaltcopper-gold deposits, in Metasedimentary rocks, chapter G of Mineral Deposit Models for Resource 
Assessment (ver.1.1, March 14, 2014). U.S. Geological Survey Scientific Investigations Report 2010-5070-G, 5-7, available online at http://pubs.usgs.gov/of/2010/1212/.

Slack, J.F., Aleinikoff, J.N., Belkin, H.E., Fanning, C.M., and Ransom, P.W., 2008. Mineral chemistry and SHRIMP $\mathrm{U}-\mathrm{Pb}$ geochronology of Mesoproterozoic polycrase-titanite veins in the Sullivan $\mathrm{Pb}-\mathrm{Zn}-\mathrm{Ag}$ deposit, British Columbia. Can. Miner. 46, 361-378.

Smoliar, M.I., Walker, R.J., Morgan, J.W., 1996, Re-Os ages of Group IIA, IIIA, IVA and IVB iron meteorites: Science, v. 271, p.1099-1102.

Stein, H.J., Morgan, J.W., and Scherstén, A., 2000. Re-Os dating of Low-Level Highly Radiogenic (LLHR) sulfides: The Harnäs gold deposit, southwest Sweden, records continental-scale tectonic events. Econ. Geol. 95, 16571671.

Trumbull, R.B., Slack, J.F., Krienitz, M.-S., Belkin, H.E., and Wiedenbeck, M., 2011. Fluid sources and metallogenesis in the Blackbird $\mathrm{Co}-\mathrm{Cu}-\mathrm{Au}-\mathrm{Bi}-\mathrm{Y}-\mathrm{REE}$ district, Idaho, USA: Insights from major element and boron isotopic compositions of tourmaline. Can. Miner. 49, 225-244.

Tunks, A., and Cooke, D., 2007. Geological and structural controls on gold mineralization in the Tanami district, Northern Territory. Mineral. Deposita 42, 107-126.

Tysdal, R.G., and Desborough, G.A., 1997. Scapolitic metaevaporite and carbonate rocks of Proterozoic Yellowjacket Formation, Moyer Creek, Salmon River Mountains, central Idaho. U.S. Geological Survey OpenFile Report OF-97-268, 26p.

Tysdal, R.G., Lund, K., and Evans, K.V., 2003. Geologic map of the west half of the Salmon National Forest. U.S. Geological Survey Misc. Invest. Series Map I-2765, scale 1: 100,000.

van Acken, D., Su, W., Gao, J., and Creaser, R.A., 2014. Preservation of Re-Os isotope signatures in pyrite throughout low-T, high-P eclogite facies metamorphism. Terra Nova 26, 402-407.

Vervoort, J.D., Lewis, R.S., Fisher, C., Gasching, R.M., Jansen, A.W., and Brewer, R., 2015. Neoarchean and Paleoproterozoic crystalline basement rocks of north-central Idaho: Constraints on the formation of western Laurentia. Geol. Soc. Amer. Bul. 128, 94-109.

Vhay, J.S., 1948. Cobalt-copper deposits in the Blackbird district, Lemhi County, Idaho. U.S. Geological Survey Strategic Minerals Invest. Prelim. Rept. 3-219, 26 p., 3 plates. 
Völkening, J., Walczyk, T., and Heumann, K., 1991. Osmium isotopic ratio determination by negative thermal ionization mass spectrometry: Intern. J. Spectro. Ionic Phy. 105, 147-159.

Walker, R.J., Morgan, J.W., Naldrett, A.J., Li, C., and Fassett, J.D., 1991. Re-Os isotope systematic of Ni-Cu sulfide ores, Sudbury igneous complex, Ontario: Evidence for a major crustal component. Earth. Pl. Sc. Let. 105, 416429.

Wang, D., 2015. Age and origin of the Archean and Paleoproterozoic basement rocks from the Priest River and Clearwater Complexes, Northern Idaho. M.S. Thesis, Pullman, Washington, Washington State University, 140 p.

Winston, D., 1986. Middle Proterozoic tectonics of the Belt Basin, western Montana and northern Idaho, in: Roberts, S.M. (Ed.), Belt Supergroup: A guide to Proterozoic rocks of western Montana and adjacent areas. Montana Bureau of Mines and Geology Special Publication 94, 245-257.

Zirakparvar, N.A., Bookstrom, A.A., and Vervoort, J.D., 2007. Cretaceous garnet growth in the Idaho cobalt belt: Evidence from Lu-Hf geochronology. Geol. Soc. Amer. Abs. Prog. 39, 413.

Zirakparvar, N.A., Vervoort, J.D., McClelland, W., and Lewis, R.S., 2010. Insights into the metamorphic evolution of the Belt-Purcell Basin: Evidence from Lu-Hf garnet geochronology. Can. J. Earth Sci. 47, 161-179.

\section{Figure captions}

Fig. 1. Geologic and tectonic maps, showing the Idaho cobalt belt (ICB), geologic surroundings in the Salmon River Mountains, and regional setting relative to selected tectonic features (modified from Bookstrom and others, 2016). A. Geologic map of the Salmon River Mountains (modified from Evans and Green, 2003) showing the geologic setting of selected Co-Cu-bearing mines, ore zones, and prospects of the ICB (from Johnson et al., 1998). Traces of the ironoxide zone and biotitic Blackbird zone (BZ) after Nash and Connor (1993). Samples from Chicago (CH) and Idaho (ID) ore zones, Haynes-Stellite mine (HS), and Black Pine prospect (BP) were collected for Re-Os analysis. Names of selected plutons and faults are spelled out, but names of the following faults are abbreviated: Big Deer fault (BDf), Little Deer fault (LDf), Salmon Canyon fault (SCf), and White Ledge fault (WLf). B. Tectonic index map (inset) showing the ICB in relation to the Mesoproterozoic Belt-Purcell Basin and the Lemhi sub-basin (after O'Neill et al., 2007; Box et al., 2012; Burmester et al., 2013). Basement domains that surround or project beneath different parts of the Belt-Purcell Basin include the Archean Wyoming Province, Medicine Hat block, and Paleoproterozoic- 
Neoarchean Clearwater block (after Vervoort et al., 2015; Wang, 2015; Kilian et al., 2016); Paleoproterozoic Selway terrane after Foster et al. (2006). Major faults of Great Falls tectonic zone (GFTZ) and thrust belt are from O’Neill (1993) and Sims et al. (2004). Perry line (PL) is a Belt Basin growth fault (after Winston, 1986). Eastern margin of the East Kootenay orogen is drawn to include sites where igneous or metamorphic minerals yield isotopic age determinations between ca. 1370 and 1320 Ma. Other features shown are the Great Divide megashear (GDM, after O’Neill et al., 2007), rifted continental margin (RCM, after O’Neill et al., 2007), and accreted oceanic terranes $(\mathrm{PzMz}=$ Paleozoic to Mesozoic $)$. Much of western Belt-Purcell Basin is overprinted by metamorphic-plutonic hinterland of the Cordilleran orogeny; eastern part is overprinted by the Cordilleran fold-and-thrust belt. Abbreviations: Cr., Creek; Grt, garnet; Sil., sillimanite.

Fig. 2. Simplified columnar stratigraphic section for Mesoproterozoic strata in the Blackbird district (modified after Bookstrom et al., 2016). Stratigraphic positions of the cobaltite mineralized bodies sampled for Re-Os work are shown as red ellipses. Blue ellipses correspond to cobaltite mineralized bodies in which U-Pb SHRIMP ages were obtained for xenotime and/or monazite texturally associated with cobaltite (Aleinikoff et al., 2012). Solid black dots represent maximum ages indicated by the youngest sets of detrital zircons in samples from each stratigraphic unit dated by Link et al. (2007) and Aleinikoff et al. (2012).

Fig. 3. Highly idealized block diagram representing thrust plates and metamorphic domains in and around the Blackbird district in the central part of the Idaho cobalt belt. Metamorphic grade is illustrated by colored infills (modified from Lund et al., 2011). Approximate locations of three cobaltite mineralized bodies (CH: Chicago zone, ID: Idaho zone, HS: Haynes-Stellite) sampled for Re-Os geochronology are shown. For explanation of map units, see Fig. 1.

Fig. 4. Photographs of the samples processed for Re-Os analyses: a. Haynes-Stellite (HS), b. Chicago zone (CH), c. Idaho zone (ID), d. Black Pine (BP). Zone "A" on the Chicago zone sample shows alternating bands of close-packed fine-grained and coarse-grained massive cobaltite.

Fig. 5. Complete workflow applied to samples presented in Figure 4.

Fig. 6. Scanning electron microscopy (SEM) back-scattered electron images of selected mineral fractions liberated from each sample following workflow presented in Figure 5 and mounted in epoxy. Figure $6 f$ is Co distribution X- 
ray map produced by scanning using an electron microprobe. Deposit abbreviations: CH, Chicago zone; HS, HaynesStellite; ID, Idaho zone; BP, Black Pine. Mineral abbreviations: K-fds, K-feldspar; Na-sil, Na-silicate; qtz, quartz.

Fig. 7. Graphical representation of variability of $\mathrm{Co}, \mathrm{Fe}$, and $\mathrm{Ni}$ contents determined by electron microprobe analysis of various mineral fractions from samples considered for Re-Os analyses. Abbreviations: CH, Chicago zone; HS, Haynes-Stellite; ID, Idaho Zone; BP, Black Pine.

Fig. 8. Conventional Re-Os isochron plot of the analyses of different magnetic fractions from Haynes-Stellite deposit (HS) and the Chicago and Idaho zones (CH and ID, respectively) in Blackbird mine. Reference isochrons with given initial ${ }^{187} \mathrm{Os} /{ }^{188}$ Os ratio $\left(\mathrm{Os}_{\mathrm{i}}\right)$ are shown for reference. Abbreviations: M x.x, magnetic fraction at current x.x amps; NM x.x, non-magnetic fraction at current x.x amps.

Fig. 9. Diagram of isochron age determination (case 1 with $n=7$, case 2 with $n=10$ ) for the Idaho zone of Blackbird mine in ${ }^{187} \mathrm{Os} /{ }^{188} \mathrm{Os}$ vs. ${ }^{187} \mathrm{Re} /{ }^{188}$ Os space. The thick bold line represents the best-fit isochron for a given number $n$ of aliquots. Individual ellipses show the error situation of each data point in ${ }^{187} \mathrm{Os} /{ }^{188}$ Os vs. ${ }^{187} \mathrm{Re} /{ }^{188}$ Os space. Ellipses are constructed from the maximum and minimum error vectors that are orthogonal to one another. Maximum and minimum errors are statistical values that are calculated from the uncertainty of the ${ }^{187} \mathrm{Os} /{ }^{188} \mathrm{Os}$ and ${ }^{187} \mathrm{Re} /{ }^{188} \mathrm{Os}$ ratios for a given data point. Empty ellipses represent three data points having high uncertainty.

Fig. 10. Diagram of isochron age determination $(n=4)$ for Haynes-Stellite deposit in ${ }^{187}$ Os $/{ }^{188}$ Os vs. ${ }^{187} \operatorname{Re} /{ }^{188}$ Os space. Empty ellipses represent two data points having high uncertainty with aliquot size below minimum of $200 \mathrm{mg}$. The thick bold line represents the best-fit isochron for a given number $n$ of aliquots. Individual ellipses show the error situation of each data point in ${ }^{187} \mathrm{Os} /{ }^{188} \mathrm{Os}$ vs. ${ }^{187} \mathrm{Re} /{ }^{188} \mathrm{Os}$ space. Ellipses are constructed from the maximum and minimum error vectors that are orthogonal to one another. Maximum and minimum errors are statistical values that are calculated from the uncertainty of the ${ }^{187} \mathrm{Os} /{ }^{188} \mathrm{Os}$ and ${ }^{187} \mathrm{Re} /{ }^{188} \mathrm{Os}$ ratios for a given data point.

Fig. 11. ${ }^{187} \mathrm{Os} /{ }^{188}$ Os vs. $1 /{ }^{192}$ Os plot to identify potential mixing relationships. The green ellipse with label " $\mathrm{CH}-\mathrm{x}, \mathrm{R}^{2}$ $=0.7709$ " shows the result of linear regression for aliquots from the Chicago zone. This linear regression evidences mixing between the original Re-Os budget of cobaltite and later (metamorphic?) fluids. The yellow ellipse shows the absence of linear trend in the case of the Idaho zone aliquots, thereby ruling out any mixing between with the Re-Os budget of cobaltite dated at ca. 1132 Ma and later fluids. 
Fig. 12. Timeline of events for the Belt-Purcell Basin and Lehmi sub-basin. Data sources: 1: Bookstrom et al. (2016); 2: this study; 3: Lund et al. (2011); 4: Aleinikoff et al. (2012); 5: Jiang et al. (2001); 6: Aleinikoff et al. (2015); 7: Evans et al. (2000); 8: Gasching et al. (2010); 9: Anderson and Davies (1995); 10: Mulder et al. (2016), 11: Slack et al. (2008). Abbreviations: BDCG: Big Deer Creek granite, Fm: Formation.

\section{Table labels}

Table 1. Blank data for Re-Os analysis. Series « $a$ » and « $b$ » indicate what blank values are appended for each analysis listed in Table 2.

Table 2. Statistical summary of electron microprobe analyses and model mineral formulae of each variably magnetic cobaltite fraction in samples from Chicago and Idaho zones in the Blackbird mine, the Haynes-Stellite deposit, and the Black Pine prospect. ICB: Idaho cobalt belt. Abbreviations: M x.x, magnetic fraction at current X.x amps; NM x.x, non-magnetic fraction at current x.x amps.

Table 3. Re-Os analytical results for the Chicago and Idaho zones in the Blackbird mine, Haynes-Stellite deposit, and Black Pine prospect. Due to low Re levels and high uncertainties in analyzed Os levels in cobaltite from Black Pine prospect, only these values are reported because other items in the Re-Os data set lack meaning. M x.x, magnetic fraction at current X.X amps; NM x.x, non-magnetic fraction at current X.X amps; side slope of $15^{\circ}$ and forward slope of $10^{\circ}$. Model ages were calculated for sample aliquots from Chicago and Idaho zones using an initial

${ }^{187} \mathrm{Os} /{ }^{188}$ Os ratio of $9 \pm 3$; model ages were calculated for aliquots from Haynes-Stellite deposit using an initial ${ }^{187} \mathrm{Os} /{ }^{188} \mathrm{Os}$ ratio of $5 \pm 2$.

\section{Electronic Supplementary Material}

ESM 1. Full data set of electron microprobe analyses of each variably magnetic cobaltite fraction in Chicago and Idaho zones of Blackbird mine, Haynes-Stellite deposit, and Black Pine prospect. Detection limits are: 0.02 wt.\% for Zn, 0.01 wt. \% for Fe, 0.03 wt.\% for $\mathrm{Ni}, 0.02$ wt.\% for $\mathrm{Cu}, 0.02 \mathrm{wt} . \%$ for $\mathrm{S}, 0.12 \mathrm{wt} . \%$ for $\mathrm{Se}, 0.07 \mathrm{wt} . \%$ for Te, and 0.09 wt. $\%$ for Bi. 
Cordilleran metamorphic and plutonic activity margin of Laurentia

cobaltite Age of sericite around late

\section{$1132 \pm 240 \mathrm{Ma}$}

$$
1370 \pm 4 \mathrm{Ma} \quad \text { ca. } 1300 \text { to } 1270 \mathrm{Ma}
$$

Merle prospect xenotime $1058 \pm 11 \mathrm{Ma}$

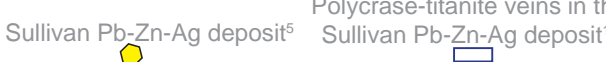

$$
\text { ca. } 1470 \mathrm{Ma}
$$$$
1413 \pm 4 \mathrm{Ma}
$$

\section{East Kootenay orogeny}

ca. 1379 to $1325 \mathrm{Ma}$

max Yellowjacket Fm (base not exposed) monazite monazite

$110 \pm 3 \mathrm{Ma} 92 \pm 5 \mathrm{Ma}$

hydrothermal event
in the Belt-Purcell Basin

hydrothermal xenotime (Belt Supergroup

Grenvillian orogeny

$1041 \pm 42 \mathrm{Ma}$ Onset of Cretaceous metamorphism $1454 \pm 9 \mathrm{Ma}$

max age, bottom of Apple Creek Fm (host horizon) max age, top of Apple Creek Fm (host horizon)

$$
1445 \pm 12 \mathrm{Ma} \quad 1409 \pm 10 \mathrm{Ma}
$$

Volcanism/ Moyie sills Purcell lava $1383 \pm 4 \mathrm{Ma} \quad B D C G$

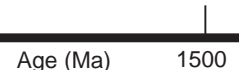

$1468 \pm 2 \mathrm{Ma} \quad 1443 \pm 7 \mathrm{Ma}$

$1383 \pm 4 \mathrm{Ma} \quad 1377 \pm 4 \mathrm{Ma} \quad 1359 \pm 7 \mathrm{Ma}$

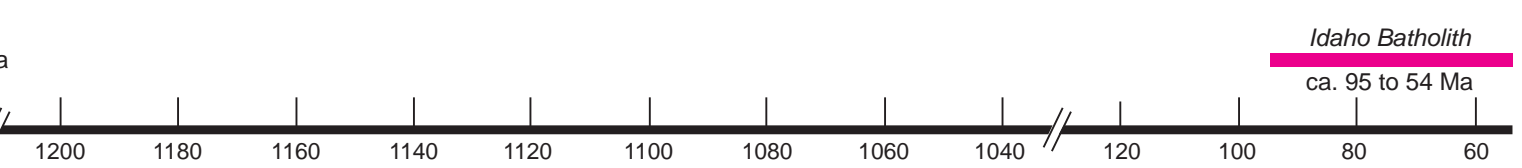




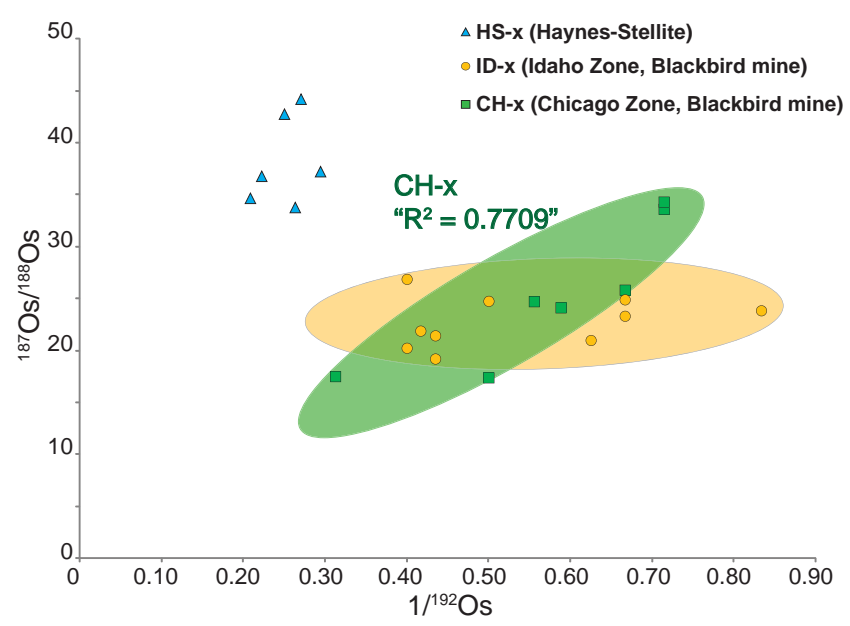




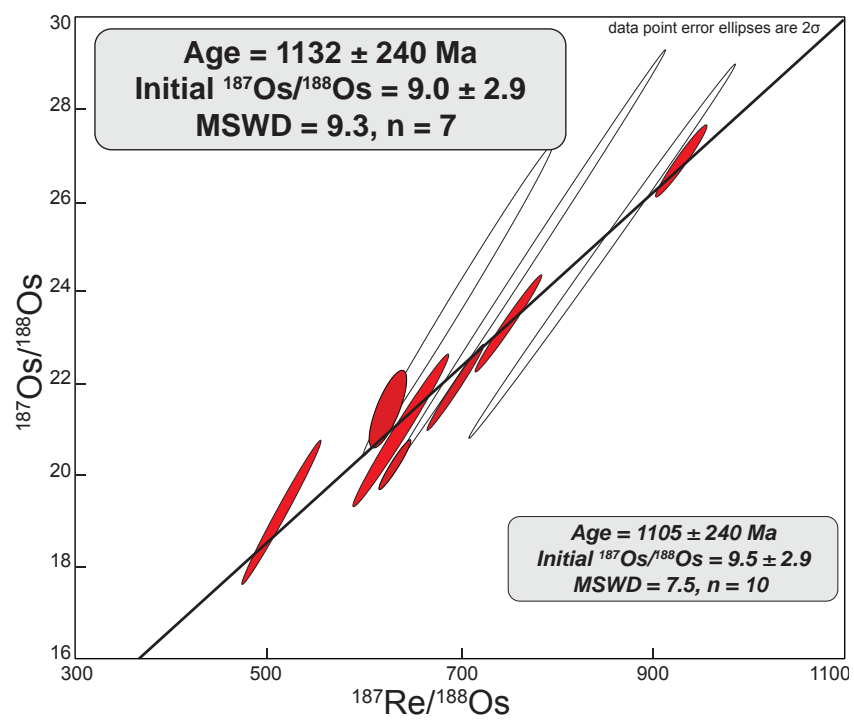




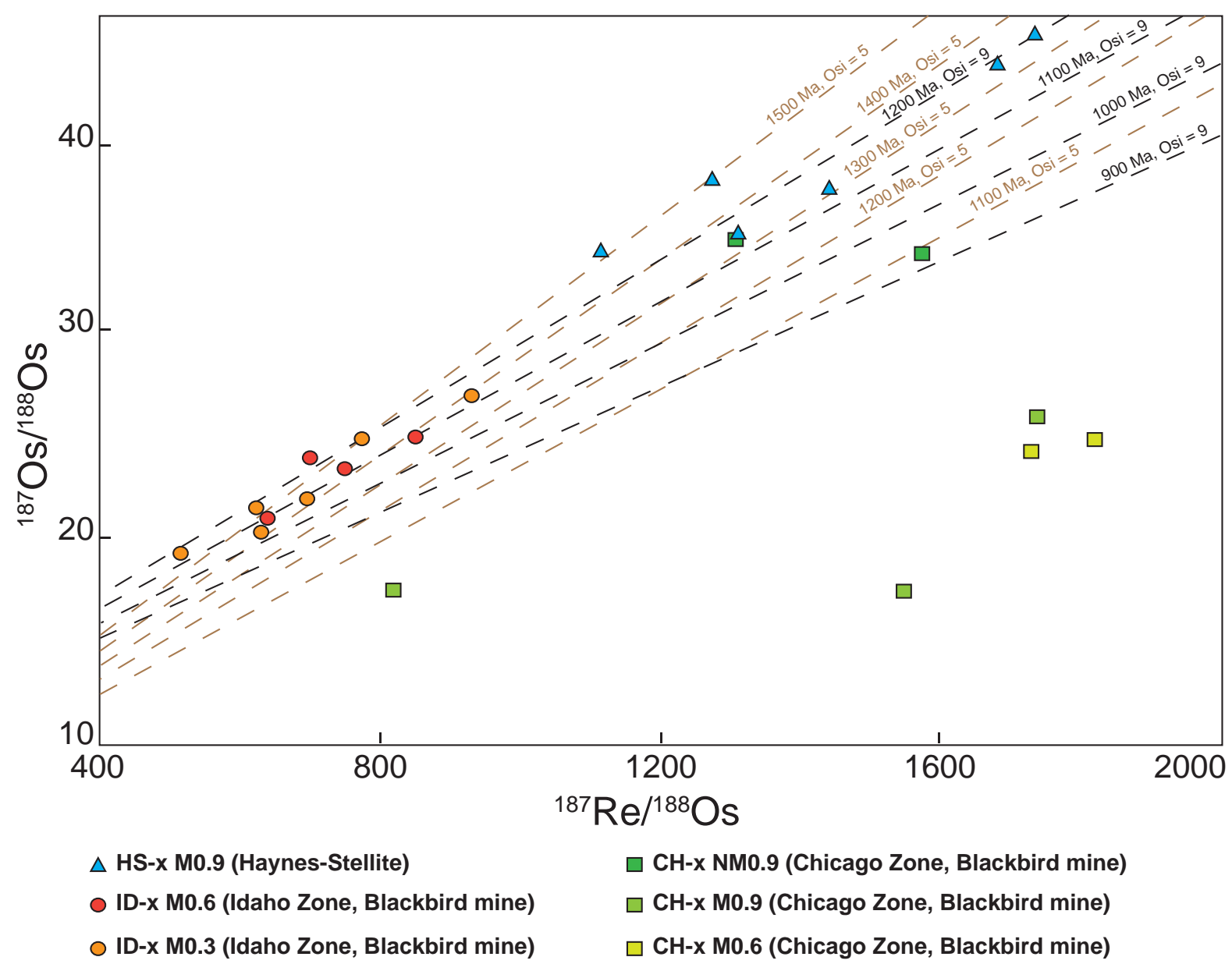




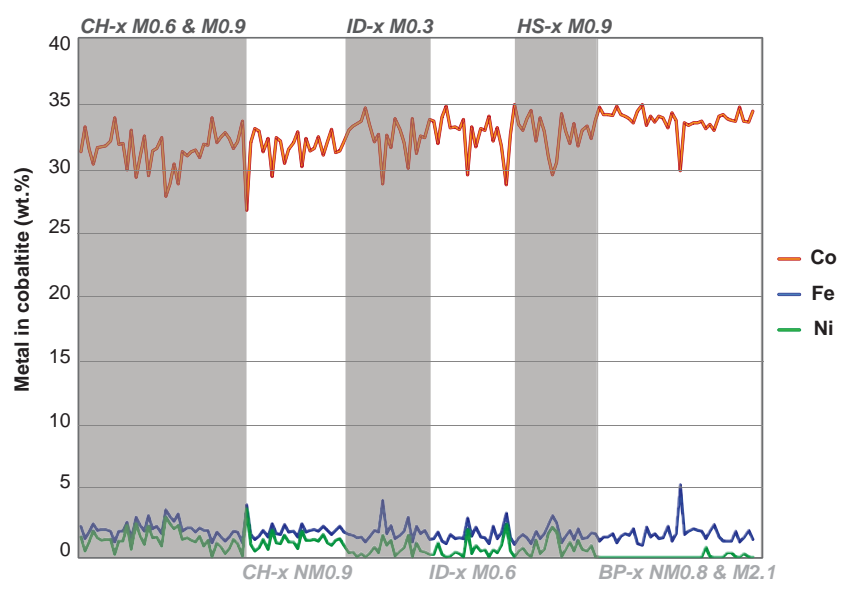



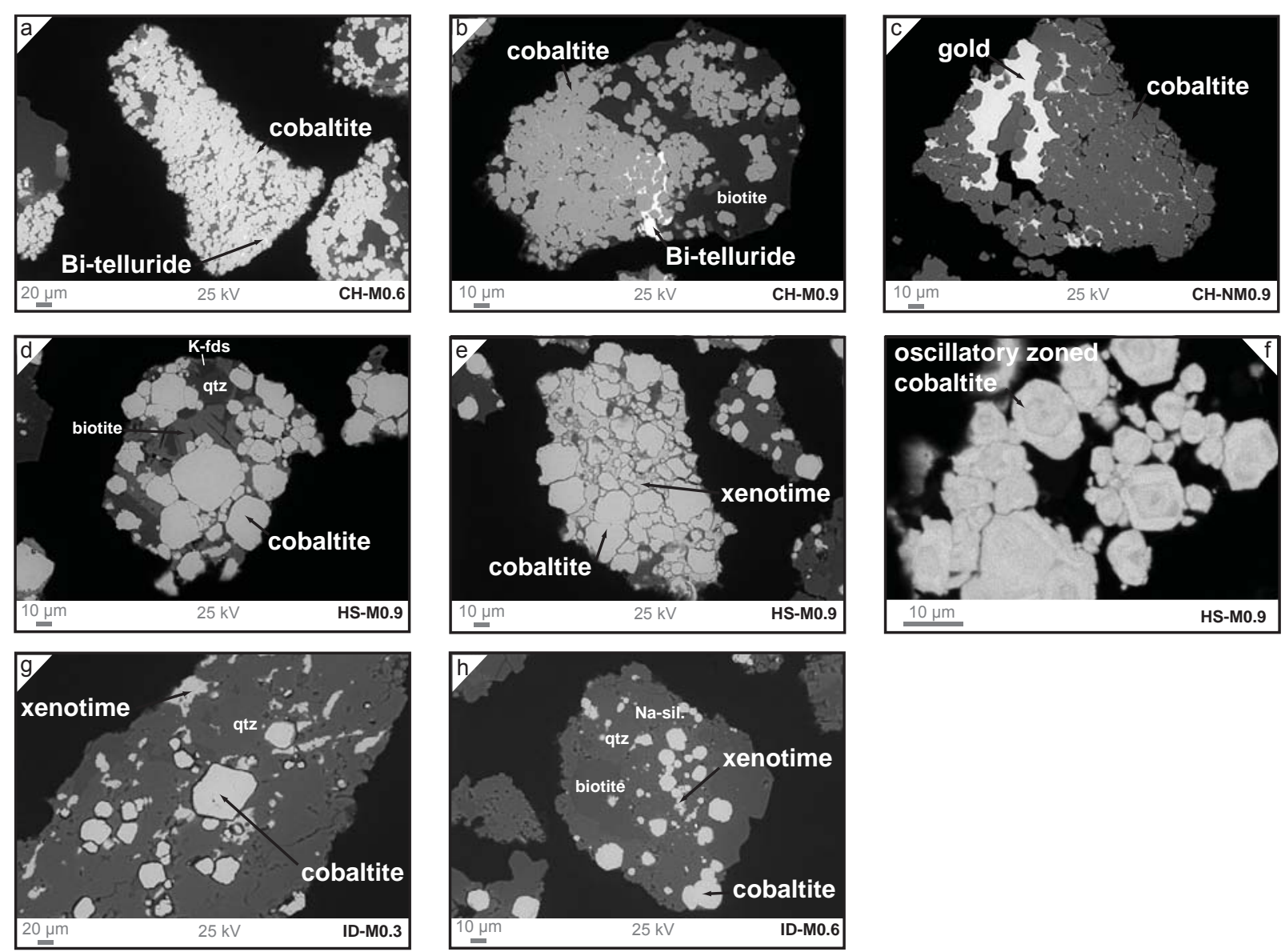


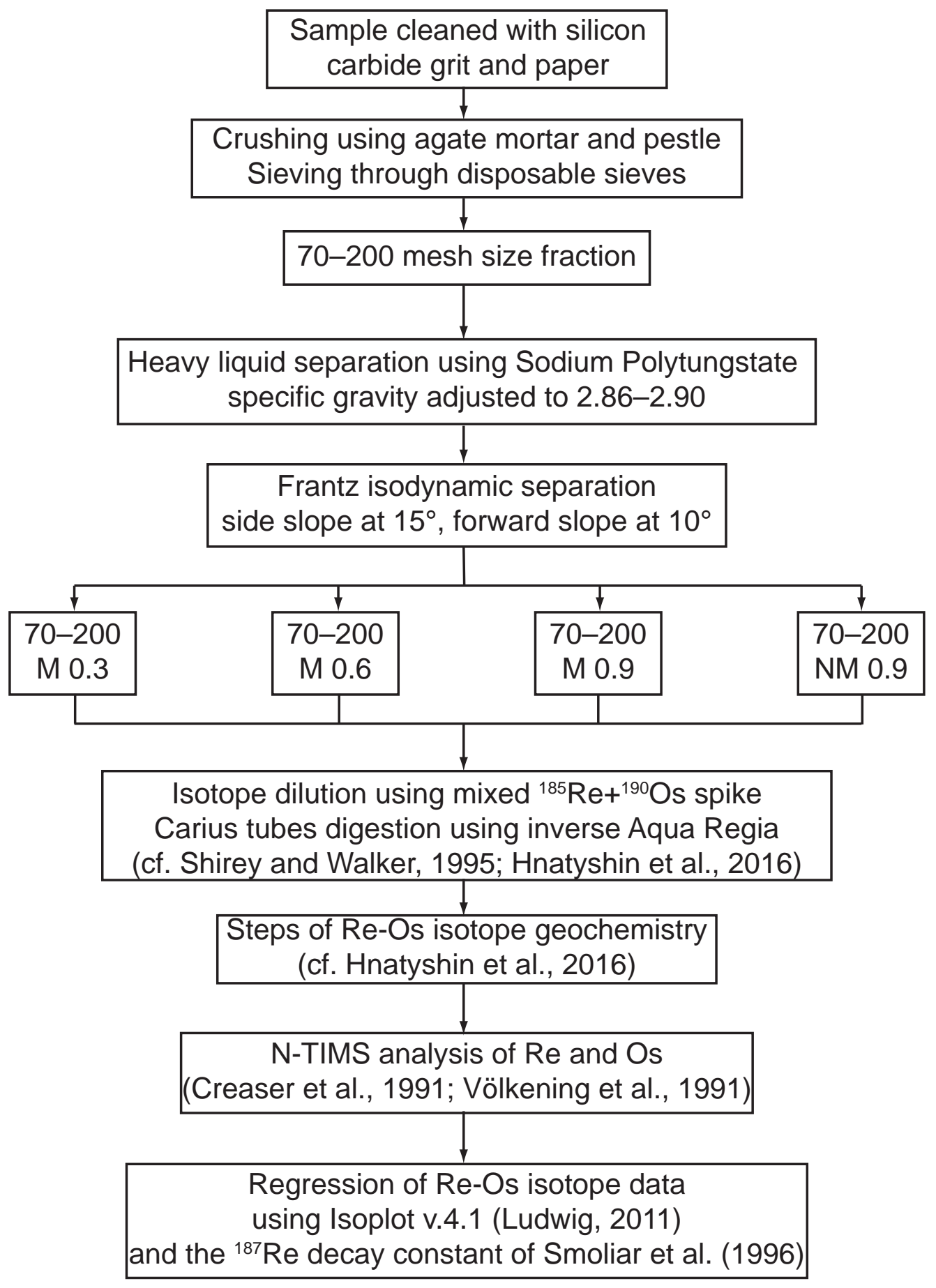




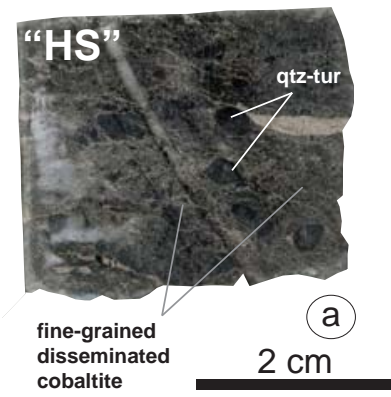

cobaltite

coarse-grained massive

$\mathrm{A}[$

massive cobaltite

$2 \mathrm{~cm}$

"CH"
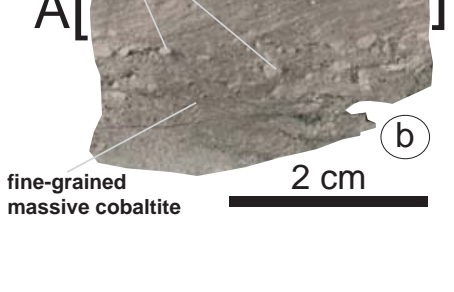

fine-grained

disseminated

cobaltite

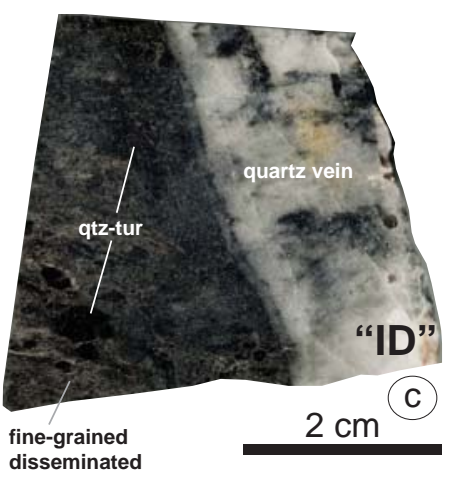

Coarse-grained cobaltite

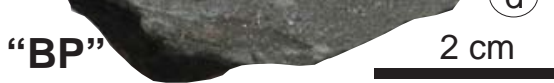




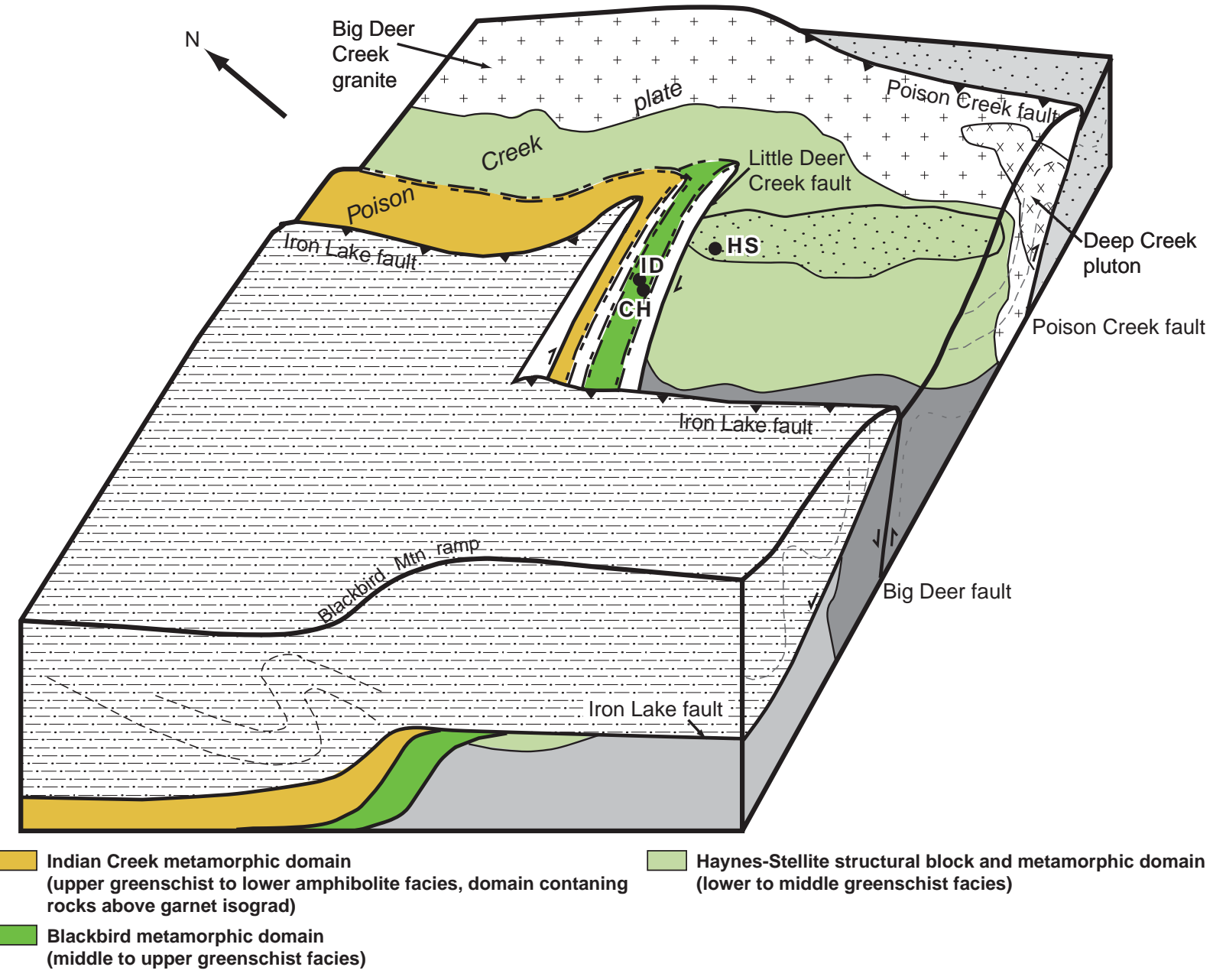




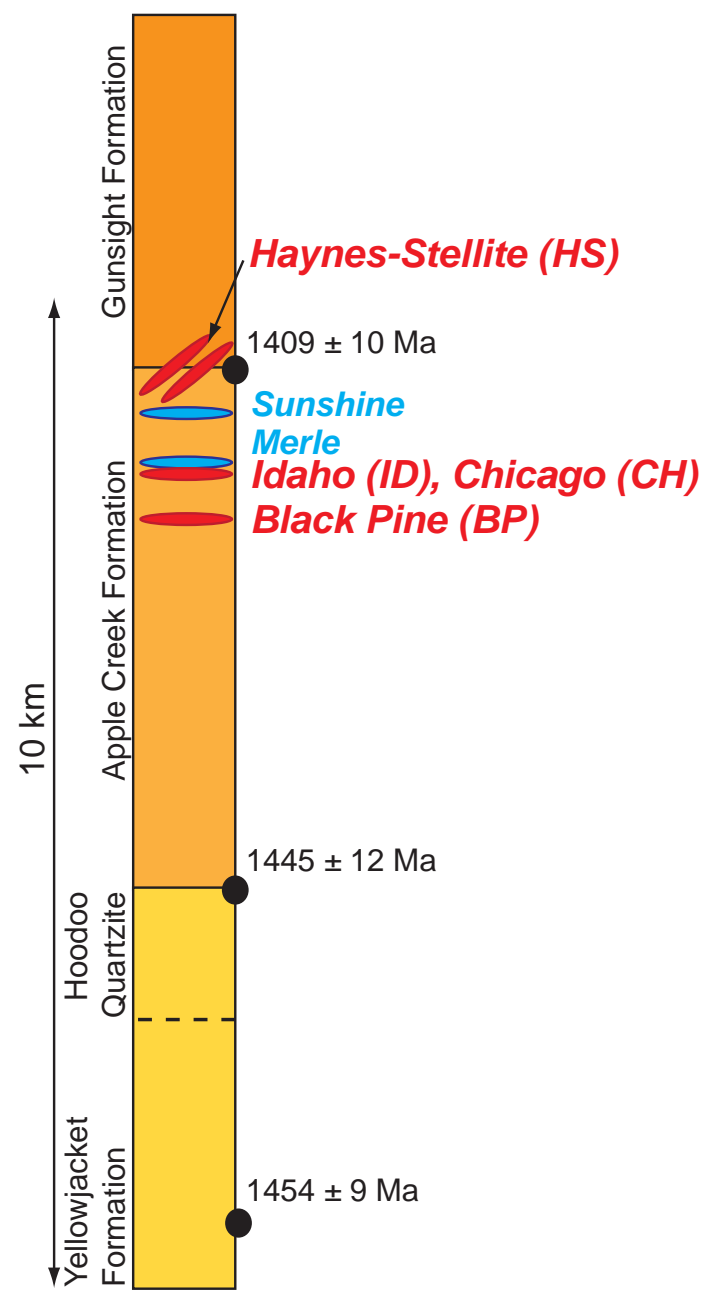




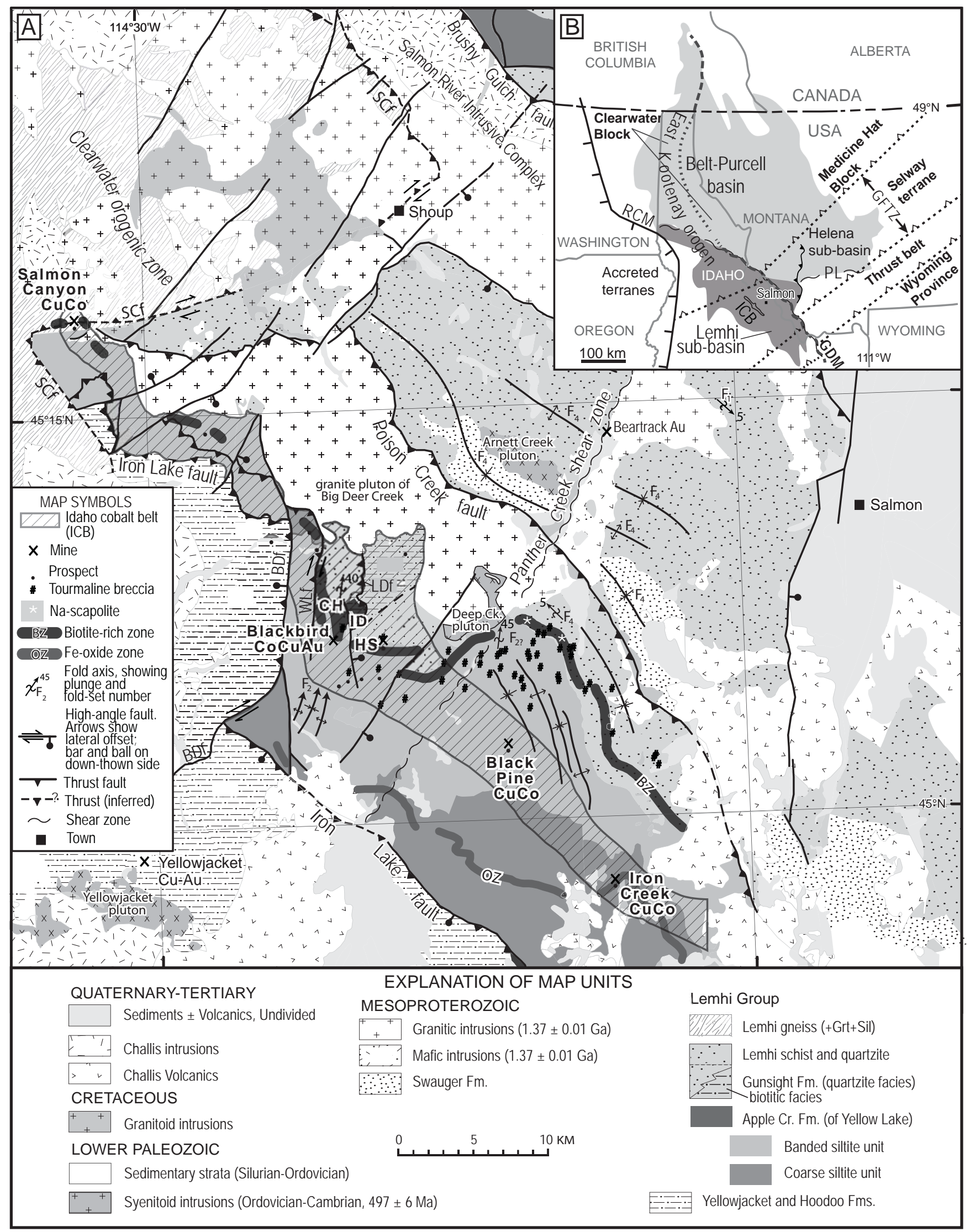




\begin{tabular}{|c|c|c|c|c|c|c|c|c|c|c|c|c|c|c|c|c|c|c|c|c|c|c|c|c|c|}
\hline Sample & $\begin{array}{l}\text { Granulometry } \\
\text { (mesh size) }\end{array}$ & $\begin{array}{c}\text { Magnetic } \\
\text { fraction } \\
\left(15^{\circ} / 10^{\circ}\right)\end{array}$ & Mineralogy & $\begin{array}{c}\text { Sample weight } \\
(\mathrm{mg})\end{array}$ & $\begin{array}{l}\text { Blank series } \\
\text { in Table } 1\end{array}$ & $\begin{array}{c}\mathrm{Re} \\
(\mathrm{ppb})\end{array}$ & $\pm 2 \sigma$ & $\begin{array}{l}\text { Os } \\
\text { (ppt) }\end{array}$ & $\pm 2 \sigma$ & ${ }^{187} \mathrm{Re}^{\mathrm{e}{ }^{188} \mathrm{Os}}$ & $\pm 2 \sigma$ & ${ }^{187} \mathrm{O} / /^{188} \mathrm{Os}$ & $\pm 2 \sigma$ & rho & $\begin{array}{l}{ }^{192} \mathrm{Os} \\
(\mathrm{ppt})\end{array}$ & $\begin{array}{l}{ }^{187} \mathrm{Re} \\
(\mathrm{ppb})\end{array}$ & $\pm 2 \sigma$ & $\begin{array}{l}{ }^{187} \mathrm{Os}^{*} \\
(\mathrm{ppt})\end{array}$ & $\pm 2 \mathrm{~s}$ & ${ }^{187} \mathrm{Os}^{*}$ & \%Re blank & ${ }^{187}$ Os blank & ${ }^{188}$ Os blank & $\begin{array}{l}\text { Model } \\
\text { age } \\
\text { (Myr) }\end{array}$ & $\pm 2 \sigma$ \\
\hline$\overline{\mathrm{BP}-01}$ & +70 & $\begin{array}{ll}\mathrm{M} 0.8 \\
\end{array}$ & cobaltite \pm chlorite \pm quartz & 109.70 & $\mathrm{a}$ & 0.295 & 0.004 & & 11.3 & & & - & - & & & & & & - & - & - & - & - & & \\
\hline $\begin{array}{l}\mathrm{B} P-02 \\
\mathrm{BP}-02\end{array}$ & +70 & NM0.8 & cobaltite \pm chlorite \pm quartz & 71.40 & a & 0.135 & 0.005 & 0.8 & 4.0 & $=$ & $=$ & $=$ & $=$ & - & - & $=$ & $=$ & - & - & - & $=$ & $=$ & $=$ & - & - \\
\hline BP-03 & $70-200$ & M1.9 & cobaltite \pm chlorite \pm quartz & 36.00 & a & $<0.100$ & 0.010 & & & - & - & - & - & - & - & - & - & - & - & - & - & - & - & - & . \\
\hline$\frac{\mathrm{BP}-04}{\mathrm{CH}-01}$ & $\frac{70-200}{70-200}$ & M2.1 & $\frac{\text { cobaltite } \pm \text { chlorite } \pm \text { quartz }}{\text { cobaltite }+ \text { xenotime } \text { quartz }}$ & $\frac{96.30}{77.40}$ & $\frac{a}{a}$ & $\frac{0.117}{1.127}$ & $\frac{0.004}{0.008}$ & $\frac{0.2}{18.6}$ & $\frac{1.9}{9.5}$ & $\frac{-}{1571}$ & $\frac{-}{696}$ & $\frac{-}{33.63}$ & $\frac{-}{14.90}$ & $\frac{-}{0.999}$ & $\begin{array}{c}- \\
1.4\end{array}$ & $\frac{-}{0.708}$ & $\begin{array}{c}- \\
0.005\end{array}$ & $\frac{-}{10.6}$ & $\frac{-}{3}$ & $\frac{-}{57}$ & $\frac{-}{5.05}$ & $\frac{-}{3.96}$ & $\overline{83}$ & $\frac{-}{934}$ & 274 \\
\hline $\mathrm{CH}-02$ & $\begin{array}{l}0-200 \\
70-200\end{array}$ & M0.9 & $\begin{array}{l}\text { cobaltite } \pm \text { xenotime } \pm \text { quartz } \\
\text { contit }\end{array}$ & $\begin{array}{l}77.40 \\
53.90\end{array}$ & $\begin{array}{l}a \\
a\end{array}$ & $\begin{array}{l}1.127 \\
1.574\end{array}$ & 0.011 & 16.0 & 7.2 & 1545 & 692 & 17.40 & 7.80 & 0.999 & 2.0 & 0.990 & 0.007 & 4.7 & 4 & 30 & 5.19 & 7.74 & 83 & 326 & 280 \\
\hline CH-03 & $70-200$ & м0.6 & $\begin{array}{l}\text { cobaltite } \pm \text { xenotime } \pm \text { quartz } \pm \\
\text { biotite }\end{array}$ & 93.58 & a & 1.626 & 0.009 & 18.1 & 5.8 & 1818 & 532 & 24.74 & 7.25 & 0.999 & 1.8 & 1.022 & 0.006 & 8.3 & 3 & 46 & 2.89 & 3.57 & 77 & 517 & 216 \\
\hline CH- 04 & $70-200$ & М0.6 & $\begin{array}{l}\text { cobaltite } \pm \text { xenotime } \pm \text { quartz } \pm \\
\text { biotite }\end{array}$ & 351.90 & a & 1.500 & 0.008 & 17.3 & 1.5 & 1729 & 139 & 24.15 & 1.94 & 0.997 & 1.7 & 0.943 & 0.005 & 7.7 & 2 & 45 & 0.83 & 1.00 & 47 & 524 & 209 \\
\hline CH-05 & $70-200$ & M0.9 & cobaltite \pm xenotime \pm quartz & 427.09 & a & 1.336 & 0.007 & 16.1 & 1.3 & 1736 & 130 & 25.85 & 1.93 & 0.996 & 1.5 & 0.839 & 0.004 & 7.7 & 2 & 47 & 0.77 & 0.87 & 45 & 580 & 208 \\
\hline CH-06 & $70-200$ & NM0.9 & cobaltite \pm xenotime \pm quartz & 545.87 & $\mathrm{a}$ & 0.925 & 0.005 & 18.7 & 1.8 & 1304 & 101 & 34.33 & 3.08 & 0.859 & 1.4 & 0.581 & 0.003 & 10.8 & 2 & 58 & 0.87 & 0.56 & 41 & 1155 & 285 \\
\hline CH-07 & $70-200$ & M0.9 & cobaltite \pm xenotime \pm quartz & 349.85 & $\mathrm{a}$ & 1.319 & 0.007 & 25.4 & 1.9 & 817 & 56 & 17.52 & 1.40 & 0.853 & 3.2 & 0.829 & 0.004 & 7.6 & 4 & 30 & 0.95 & 0.75 & 33 & 623 & 444 \\
\hline HS-01 & $70-200$ & M0.9 & $\begin{array}{l}\text { cobaltite } \pm \text { tourmaline } \pm \\
\text { xenotime } \pm \text { biotite } \pm \text { K-feldspar } \\
\pm \text { quartz } \\
\text { cobaltite } \pm \text { tourmaline } \pm\end{array}$ & 51.57 & a & 2.186 & 0.013 & 48.4 & 15.8 & 1273 & 352 & 37.26 & 10.31 & 0.999 & 3.4 & 1.374 & 0.008 & 29.4 & 5 & 61 & 3.90 & 2.24 & 76 & 1503 & 198 \\
\hline HS-02 & $70-200$ & M0.9 & $\begin{array}{l}\text { xenotime } \pm \text { biotite } \pm K \text {-feldspar } \\
\pm \text { quartz } \\
\text { cobaltite } \pm \text { tourmaline } \pm\end{array}$ & 311.90 & $\mathrm{a}$ & 3.131 & 0.016 & 63.5 & 2.7 & 1309 & 47 & 34.69 & 1.32 & 0.920 & 4.8 & 1.968 & 0.010 & 37.1 & 6 & 58 & 0.45 & 0.29 & 27 & 1346 & 183 \\
\hline HS-03 & $70-200$ & М0.9 & $\begin{array}{l}\text { xenotime } \pm \text { biotite } \pm \text { K-feldspar } \\
\pm \text { quarz } \\
\text { cobaltite } \pm \text { tourmaline } \pm\end{array}$ & 205.30 & b & 3.258 & 0.014 & 63.1 & 2.4 & 1438 & 38 & 36.82 & 1.39 & 0.688 & 4.5 & 2.048 & 0.009 & 38.2 & 6 & 60 & 0.34 & 0.07 & 3 & 1313 & 170 \\
\hline HS-04 & 70-200 & M0.9 & $\begin{array}{l}\text { xenotime } \pm \text { biotite } \pm \text { K-feldspar } \\
\pm \text { quartz } \\
\text { cobaltite } \pm \text { tourmaline } \pm\end{array}$ & 266.37 & b & 3.398 & 0.014 & 64.0 & 1.1 & 1680 & 25 & 42.80 & 0.63 & 0.932 & 4.0 & 2.136 & 0.009 & 41.7 & 5 & 65 & 0.25 & 0.05 & 3 & 1336 & 142 \\
\hline HS-05 & 70-200 & M0.9 & $\begin{array}{l}\text { xenotime } \pm \text { biotite } \pm K \text { - feldspar } \\
\pm \text { quart } \\
\text { cobaltite } \pm \text { tourmaline } \pm\end{array}$ & 145.75 & b & 2.106 & 0.009 & 49.1 & 1.6 & 1114 & 31 & 33.8 & 1.0 & 0.971 & 3.8 & 1.323 & 0.006 & 28.3 & 5 & 58 & 0.75 & 0.13 & 5 & 1533 & 213 \\
\hline HS-06 & $70-200$ & M0.9 & $\begin{array}{l}\text { xenotime } \pm \text { biotite } \pm K \text {-feldspar } \\
\pm \text { quartz }\end{array}$ & 268.79 & b & 3.202 & 0.013 & 60.2 & 1.2 & 1732 & 28 & 44.24 & 0.71 & 0.941 & 3.7 & 2.012 & 0.008 & 39.8 & 5 & 66 & 0.27 & 0.06 & 3 & 1345 & 137 \\
\hline ID-01 & 70-200 & M0.3 & cobaltite \pm biotite \pm & 158.90 & a & 0.791 & 0.005 & 20.8 & 3.4 & 771 & 116 & 24.77 & 3.72 & 0.999 & 2.0 & 0.497 & 0.003 & 9.5 & 3 & 46 & 3.50 & 1.83 & 63 & 1216 & 474 \\
\hline ID-02 & 70-200 & м0.6 & $\begin{array}{l}\text { cobaltite } \pm \text { biotite } \pm \text { quartz } \pm \\
\text { xenotime }\end{array}$ & 238.60 & a & 0.650 & 0.004 & 15.7 & 2.3 & 847 & 113 & 24.9 & 3.3 & 0.999 & 1.5 & 0.497 & 0.002 & 7.2 & 2 & 46 & 2.84 & 1.62 & 60 & 1117 & 430 \\
\hline ID-03 & $70-200$ & М0.3 & cobaltite \pm biotite \pm xenotime & 100.86 & b & 0.589 & 0.004 & 19.3 & 1.3 & 512 & 34 & 19.22 & 1.28 & 0.989 & 2.3 & 0.370 & 0.003 & 6.7 & 3 & 34 & 3.87 & 0.55 & 12 & 1186 & 700 \\
\hline ID-04 & $70-200$ & М0.3 & cobaltite \pm biotite \pm xenotime & 332.57 & $\mathrm{~b}$ & 0.729 & 0.003 & 21.4 & 0.6 & 622 & 16 & 21.45 & 0.69 & 0.759 & 2.3 & 0.458 & 0.002 & 8.4 & 3 & 40 & 0.95 & 0.15 & 4 & 1190 & 575 \\
\hline ID-05 & $70-200$ & M0.6 & $\begin{array}{l}\text { cobaltite } \pm \text { biotite } \pm \text { quartz } \pm \\
\text { xenotime }\end{array}$ & 107.94 & b & 0.425 & 0.004 & 12.0 & 1.5 & 697 & 81 & 23.87 & 2.78 & 0.995 & 1.2 & 0.267 & 0.002 & 5.3 & 2 & 44 & 5.01 & 0.77 & 19 & 1267 & 519 \\
\hline ID-06 & $70-200$ & М0.6 & $\begin{array}{l}\text { cobaltite } \pm \text { biotite } \pm \text { quartz } \pm \\
\text { xenotime }\end{array}$ & 267.67 & $\mathrm{~b}$ & 0.578 & 0.003 & 15.0 & 0.6 & 749 & 28 & 23.33 & 0.87 & 0.985 & 1.5 & 0.364 & 0.002 & 6.5 & 2 & 43 & 1.49 & 0.25 & 7 & 1138 & 477 \\
\hline ID-07 & $70-200$ & м0.3 & cobaltite \pm biotite \pm xenotime & 260.97 & b & 1.154 & 0.005 & 26.9 & 0.7 & 929 & 22 & 26.89 & 0.65 & 0.969 & 2.5 & 0.725 & 0.003 & 13.2 & 3 & 49 & 0.76 & 0.14 & 4 & 1145 & 384 \\
\hline ID-08 & $70-200$ & М0.6 & $\begin{array}{l}\text { cobaltitie } \pm \text { biotite } \pm \text { quartz } \pm \\
\text { xenotime }\end{array}$ & 150.03 & $\mathrm{~b}$ & 0.511 & 0.003 & 14.4 & 1.0 & 637 & 41 & 21.00 & 1.35 & 0.986 & 1.6 & 0.321 & 0.002 & 5.5 & 2 & 39 & 3.00 & 0.48 & 11 & 1121 & 563 \\
\hline ID-09 & $70-200$ & М0.3 & cobaltite \pm biotite \pm xenotime & 288.17 & b & 0.794 & 0.003 & 22.0 & 0.5 & 630 & 14 & 20.26 & 0.44 & 0.954 & 2.5 & 0.499 & 0.002 & 8.1 & 3 & 37 & 1.00 & 0.17 & 4 & 1063 & 567 \\
\hline ID-10 & $70-200$ & М0.3 & cobaltite \pm biotite \pm xenotime & 182.00 & b & 0.840 & 0.004 & 22.4 & 0.8 & 695 & 24 & 21.91 & 0.77 & 0.986 & 2.4 & 0.528 & 0.002 & 16.6 & 0 & 74 & 1.50 & 0.25 & 7 & 1105 & 514 \\
\hline
\end{tabular}




\begin{tabular}{|c|c|c|c|c|c|c|c|c|c|c|c|c|c|c|}
\hline Mineral fraction & & $\begin{array}{l}\mathrm{Zn} \\
(\mathrm{wt} \%)\end{array}$ & $\begin{array}{l}\text { Fe } \\
(w t \%)\end{array}$ & $\begin{array}{l}\text { Co } \\
\text { (wt \%) } \\
\end{array}$ & $\begin{array}{l}\mathrm{Ni} \\
\text { (wt \%) } \\
\end{array}$ & $\begin{array}{l}\mathrm{Cu} \\
(\mathrm{wt} \%)\end{array}$ & $\begin{array}{l}\text { S } \\
\text { (wt \%) } \\
\end{array}$ & $\begin{array}{l}\text { As } \\
\text { (wt \%) } \\
\end{array}$ & $\begin{array}{l}\text { Se } \\
\text { (wt \%) } \\
\end{array}$ & $\begin{array}{l}\text { Te } \\
\text { (wt \%) } \\
\end{array}$ & $\begin{array}{l}\text { Bi } \\
(w t \%)\end{array}$ & Modal mineral formula & $\begin{array}{l}\text { Metamorphic grade in the } \\
\text { structural block }\end{array}$ & $\begin{array}{c}\text { Position in } \\
\text { the ICB }\end{array}$ \\
\hline CH M 0.6 & Min & 0.00 & 1.16 & 29.49 & 0.17 & 0.00 & 18.50 & 46.02 & 0.00 & 0.00 & 0.00 & $\mathrm{~S}_{0.97} \mathrm{Fe}_{0.06} \mathrm{Co}_{0.89} \mathrm{Ni}_{0.04} \mathrm{As}_{1.03}$ & middle to upper greenschist & \\
\hline \multirow[t]{3}{*}{$(\mathrm{n}=20)$} & $\operatorname{Max}$ & 0.03 & 3.21 & 34.06 & 2.55 & 0.00 & 19.32 & 46.92 & 0.00 & 0.09 & 0.05 & & & \\
\hline & average & 0.01 & 2.15 & 31.72 & 1.38 & 0.00 & 18.81 & 46.57 & 0.00 & 0.02 & 0.00 & & & W \\
\hline & Standard deviation & 0.01 & 0.51 & 1.18 & 0.63 & 0.00 & 0.21 & 0.27 & 0.00 & 0.03 & 0.01 & & & \\
\hline СH M 0.9 & Min & 0.00 & 1.11 & 26.91 & 0.03 & 0.00 & 18.78 & 45.93 & 0.00 & 0.00 & 0.00 & $\mathrm{~S}_{0.98} \mathrm{Fe}_{0.07} \mathrm{Co}_{0.88} \mathrm{Ni}_{0.04} \mathrm{As}_{1.03}$ & middle to upper greenschist & \\
\hline \multirow[t]{3}{*}{$(\mathrm{n}=20)$} & Max & 0.03 & 4.06 & 34.05 & 3.70 & 0.00 & 19.20 & 47.03 & 0.00 & 0.11 & 0.20 & & & \\
\hline & average & 0.00 & 2.20 & 31.29 & 1.41 & 0.00 & 18.92 & 46.37 & 0.00 & 0.02 & 0.01 & & & \\
\hline & Standard deviation & 0.01 & 0.81 & 1.84 & 0.96 & 0.00 & 0.12 & 0.30 & 0.00 & 0.03 & 0.04 & & & \\
\hline CH NM 0.9 & Min & 0.00 & 1.33 & 29.52 & 0.47 & 0.00 & 18.72 & 45.35 & 0.00 & 0.00 & 0.00 & $\mathrm{~S}_{0.99} \mathrm{Fe}_{0.06} \mathrm{Co}_{0.90} \mathrm{Ni}_{0.03} \mathrm{As}_{1.02}$ & middle to upper greenschist & \\
\hline \multirow[t]{3}{*}{$(n=22)$} & Max & 0.02 & 2.58 & 33.21 & 2.06 & 0.00 & 19.95 & 46.44 & 0.36 & 0.00 & 0.79 & & & \\
\hline & average & 0.00 & 1.98 & 31.91 & 1.20 & 0.00 & 19.10 & 45.88 & 0.05 & 0.00 & 0.08 & & & \\
\hline & Standard deviation & 0.01 & 0.52 & 6.57 & 0.46 & 0.00 & 3.90 & 9.36 & 0.08 & 0.00 & 0.20 & & & \\
\hline ID M 0.3 & Min & 0.00 & 1.15 & 28.93 & 0.00 & 0.00 & 18.83 & 44.40 & 0.00 & 0.00 & 0.00 & $\mathrm{~S}_{0.99} \mathrm{Fe}_{0.06} \mathrm{Co}_{0.92} \mathrm{Ni}_{0.02} \mathrm{As}_{1.01}$ & middle to upper greenschist & \\
\hline \multirow[t]{3}{*}{$(\mathrm{n}=20)$} & Max & 0.01 & 4.39 & 34.83 & 1.65 & 0.00 & 19.53 & 46.67 & 0.00 & 0.11 & 0.03 & & & \\
\hline & average & 0.00 & 1.96 & 32.65 & 0.59 & 0.00 & 19.14 & 45.61 & 0.00 & 0.03 & 0.00 & & & \\
\hline & Standard deviation & 0.00 & 0.73 & 1.38 & 0.51 & 0.00 & 0.20 & 0.55 & 0.00 & 0.03 & 0.01 & & & \\
\hline ID M 0.6 & Min & 0.00 & 1.01 & 28.85 & 0.00 & 0.00 & 18.69 & 44.82 & 0.00 & 0.00 & 0.00 & $\mathrm{~S}_{0.99} \mathrm{Fe}_{0.05} \mathrm{Co}_{0.93} \mathrm{Ni}_{0.02} \mathrm{As}_{1.02}$ & middle to upper greenschist & \\
\hline \multirow[t]{3}{*}{$(\mathrm{n}=20)$} & Max & 0.02 & 3.39 & 34.99 & 2.53 & 0.00 & 19.59 & 46.40 & 0.00 & 0.07 & 0.02 & & & \\
\hline & average & 0.01 & 2.15 & 31.72 & 1.38 & 0.00 & 18.81 & 46.57 & 0.00 & 0.02 & 0.00 & & & \\
\hline & Standard deviation & 0.00 & 0.62 & 1.48 & 0.68 & 0.00 & 0.22 & 0.39 & 0.00 & 0.03 & 0.01 & & & \\
\hline HS M 0.9 & Min & 0.00 & 0.94 & 29.62 & 0.00 & 0.00 & 18.77 & 46.27 & 0.00 & 0.00 & 0.00 & $\mathrm{~S}_{0.98} \mathrm{Fe}_{0.05} \mathrm{Co}_{0.92} \mathrm{Ni}_{0.02} \mathrm{As}_{1.02}$ & lower to middle greenschist & \\
\hline \multirow[t]{3}{*}{$(\mathrm{n}=19)$} & Max & 0.01 & 3.19 & 35.08 & 2.28 & 0.00 & 19.65 & 46.87 & 0.00 & 0.12 & 0.00 & & & \\
\hline & average & 0.00 & 1.75 & 32.90 & 0.78 & 0.00 & 19.11 & 46.61 & 0.00 & 0.03 & 0.00 & & & \\
\hline & Standard deviation & 0.00 & 0.56 & 1.36 & 0.65 & 0.00 & 0.22 & 0.16 & 0.00 & 0.03 & 0.00 & & & \\
\hline \multirow{4}{*}{$\begin{array}{l}\text { BP NM } 0.8 \\
\left(\mathrm{n}=18^{*}\right)\end{array}$} & Min & 0.00 & 1.17 & 30.00 & 0.00 & 0.00 & 18.70 & 45.69 & 0.00 & 0.00 & 0.00 & $\mathrm{~S}_{0.98} \mathrm{Fe}_{0.06} \mathrm{Co}_{0.94} \mathrm{Ni}_{0.00} \mathrm{As}_{1.02}$ & lower to middle greenschist & \\
\hline & Max & 0.03 & 5.57 & 34.87 & 0.77 & 0.01 & 19.43 & 46.89 & 0.00 & 0.09 & 0.03 & & & \\
\hline & average & 0.01 & 1.92 & 33.63 & 0.09 & 0.00 & 19.10 & 46.31 & 0.00 & 0.02 & 0.00 & & & \\
\hline & Standard deviation & 0.01 & 0.99 & 1.00 & 0.20 & 0.00 & 0.19 & 0.28 & 0.00 & 0.03 & 0.01 & & & \\
\hline ВР М 2.1 & Min & 0.00 & 0.91 & 33.28 & 0.00 & 0.00 & 18.69 & 45.57 & 0.00 & 0.00 & 0.00 & $\mathrm{~S}_{0.98} \mathrm{Fe}_{0.05} \mathrm{Co}_{0.95} \mathrm{Ni}_{0.00} \mathrm{As}_{1.02}$ & lower to middle greenschist & \\
\hline \multirow[t]{3}{*}{$(\mathrm{n}=20)$} & Max & 0.02 & 2.36 & 35.11 & 0.00 & 0.00 & 19.41 & 46.82 & 0.00 & 0.08 & 0.02 & & & \multirow{3}{*}{ E } \\
\hline & average & 0.01 & 1.61 & 34.19 & 0.00 & 0.00 & 19.04 & 46.22 & 0.00 & 0.02 & 0.00 & & & \\
\hline & Standard deviation & 0.01 & 0.40 & 0.47 & 0.00 & 0.00 & 0.19 & 0.32 & 0.00 & 0.02 & 0.00 & & & \\
\hline
\end{tabular}




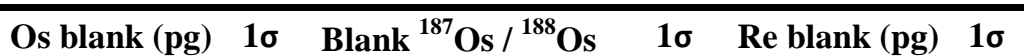

Series "a", $\mathrm{n}=3$ BLK-JDH-08, BLK-NS-15Feb16, BLK-NS-23Feb16 1.34 0.03 0.27101 0.0023 4.4 0.98

Series "b", $n=3$ BLK-NS-Aug16, BLK-NSEP-1, BLK-NSEP-2

0.08

0.05

0.79623

0.0620

2.3

0.47 